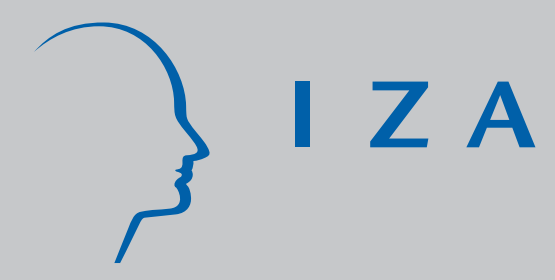

IZA DP No. 2197

A History of Canadian Recruitment of Highly Skilled Immigrants: Circa 1980-2001

Don J. DeVoretz

J uly 2006 


\title{
A History of Canadian Recruitment of Highly Skilled Immigrants: Circa 1980-2001
}

\author{
Don J. DeVoretz \\ RIIM, Simon Fraser University \\ and IZA Bonn
}

Discussion Paper No. 2197

July 2006

\author{
IZA \\ P.O. Box 7240 \\ 53072 Bonn \\ Germany \\ Phone: +49-228-3894-0 \\ Fax: +49-228-3894-180 \\ Email: iza@iza.org
}

\begin{abstract}
Any opinions expressed here are those of the author(s) and not those of the institute. Research disseminated by IZA may include views on policy, but the institute itself takes no institutional policy positions.

The Institute for the Study of Labor (IZA) in Bonn is a local and virtual international research center and a place of communication between science, politics and business. IZA is an independent nonprofit company supported by Deutsche Post World Net. The center is associated with the University of Bonn and offers a stimulating research environment through its research networks, research support, and visitors and doctoral programs. IZA engages in (i) original and internationally competitive research in all fields of labor economics, (ii) development of policy concepts, and (iii) dissemination of research results and concepts to the interested public.
\end{abstract}

IZA Discussion Papers often represent preliminary work and are circulated to encourage discussion. Citation of such a paper should account for its provisional character. A revised version may be available directly from the author. 


\section{ABSTRACT \\ A History of Canadian Recruitment of Highly Skilled Immigrants: Circa 1980-2001}

This paper identifies the types of immigrants that Canada has recruited to foster modern Canadian economic development and assesses how effective Canada has been in recruiting and retaining these required immigrants in the 21st century. Evidence from both "balance of trade" and "balance of payments" exercises indicates that it is difficult to determine if there actually exist positive net inflows of managers and professionals during the 1982-2001 period. The entry of these highly skilled immigrants resulted from a series of distinct labour market policies adopted by Citizenship and Immigration Canada and its predecessor agencies. The paper presents evidence to support that between 1976-1990 a "tap on-tap off" policy admitted skilled immigrants to Canada only if a labour vacancy was anticipated. However, after 1990 tests reveal that the previous year's economic immigrant admissions determined the contemporary immigrant flows with a 10 month lag. Offsetting this robust admission of economic immigrants in the 1990's was the substantial outflows of previous Canadian immigrants as part of the rising phenomenon of "brain circulation". Of particular note is the large number of highly skilled Chinese who have returned to Hong-Kong after 1997. Given this "brain circulation" and the chronic underutilization of its highly trained immigrants I conclude that Canada's traditional use of immigrants as an "engine of growth" is very limited in the 21st century and suggest recruitment of foreign graduate students to revitalize the role of immigrants in Canadian development.

JEL Classification: J61, J68

Keywords: immigration policy

Corresponding author:

Don J. DeVoretz

RIIM

Simon Fraser University

Burnaby, BC, V5A 1 S6

Canada

E-mail: devoretz@sfu.ca 
"Is empiricism all you have to offer?"

Rosencrantz and Guildenstern are Dead, Tom Stoppard.

\section{Part I. Introduction and Issues}

Canada's immigration experience has been historically linked to Canada's economic development (Pomfret, 1993). This early $20^{\text {th }}$ century Canadian growth narrative relies on a trilogy of forces: trade, immigration and investment in public infrastructure to produce development. This well known parable of immigrants filling Canada's west and producing the wheat to be carried to Europe via rail and ship between 1896 and 1914 has remained Canada's unchallenged paradigm of Canadian economic growth (DeVoretz, 2000). This essay asks if a new Canadian development-immigration paradigm is emerging in the $21^{\text {st }}$ century. If so, what type of immigrant fosters modern Canadian development and how effective is Canada in recruiting these required immigrants in the $21^{\text {st }}$ century?

The modern day role of immigrants in the development process has been explored by both Canadian government commissions and Canadian academics. ${ }^{1}$ The late Economic Council of Canada in the early 1990's concluded that Canada needed to experience scale economies in manufacturing to enhance productivity. However, they favored increasing Canada's market size through free trade agreements rather than immigration to enjoy these scale economies since they felt that immigrants could be a drain on the treasury. DeVoretz and Laryea (1998) challenged this negative view of immigration as an engine of growth by suggesting that skilled immigration in the 1990's led to 'brain circulation' in the context of the then emerging NAFTA. From this viewpoint, immigration into Canada in the 1990's was seen as a counterweight to Canadian skilled emigration to the United States that resulted from both the Canada-United States FTA (1989) and later the NAFTA (1995) accords. In particular, DeVoretz and Coulombe (2005) argued that increased trade, foreign direct investment and the emergence of a trade related visa (i.e. $\mathrm{TN}$ visa) accelerated the movement of Canadian citizens in 64 skilled occupations to the United States. To compensate for this outflow and to meet the anticipated pre-2001 need for professionals and engineers Canada revamped its immigration selection system and began to recruit heavily from China (Yan Shi, 2004). In particular the Chinese decision to ease emigration restrictions in the mid 1990's completed Canada's modern day immigration cum development scenario. In short, Canada compensated for NAFTA induced Canadian skilled emigration to the United States with an aggressive recruitment of Asian skilled managers and professionals to offset this loss. Prior to September $11^{\text {th }}$, 2001 Canada's new development formula replicated Pangloss' best of all possible worlds. Namely, Canada gained its desired expanded market through the NAFTA accord and

\footnotetext{
${ }^{1}$ See A. Green and D. Green (1996) for an exposition of the historical relationship of immigration and economic growth in Canada.
} 
putatively raised its productivity through inducing highly skilled Asian immigration to Canada.

This growth strategy through trade and immigration opens a host of questions which this essay will address. In Part II I will develop an accounting framework to test the proposition that Canada was a net importer of highly skilled immigrants over the last twenty years. In particular, I will ask in what specific occupations did Canada gain or lose immigrants in this triangular movement of immigrants from Asia to Canada and then on to the United States. Moreover, I will attempt to measure the economic value of these Canadian emigrants and immigrants.

In Part III I propose and test variations of a model of skilled immigrant admissions. Evidence from this model will help refute or lend credence to the proposition that Canada was more or less successful in the post-1990 era in recruiting immigrants which produced wage and employment growth in their selected occupations and hence followed the development model that I have outlined.

Part IV investigates Canada's role in the emerging 'brain circulation' process. I will pay particular attention to the triangular movement between China (PRC), Canada and the rest of the world to see if this is Pareto improving phenomenon for Canada, the immigrant sending country and the individual immigrant.

Part V concludes with observations on the efficacy of Canada's most recent immigration policy circa 2002 in enhancing Canada's growth prospects through immigration.

The sum of the findings in these separate parts will hopefully produce a picture of how Canada has historically attempted to use immigration as an "engine of growth" and how this engine has sputtered in the $21^{\text {st }}$ century. 


\section{Part II. Accounting for Brains}

\section{A Balance of Trade in Brains}

Central to any evaluation of the potential economic impact of immigrants is an analysis of the type and numbers of immigrants as well as the economic value embedded in them. A simple balance of trade in immigrants would involve a measurement of gross and net flows of immigrants by occupation into and out of Canada. Table 1 reports the immigration and emigration from Canada of selected permanent skilled movers from a

Table 1. Balance of Trade in Professional and Managerial Immigration: 1982-2001

\begin{tabular}{|c|c|c|c|c|c|c|}
\hline & \multicolumn{2}{|c|}{ Immigration to Canada } & \multicolumn{2}{|c|}{ Out-migration to the U.S. } & \multicolumn{2}{|c|}{ Net Immigration to Canada } \\
\hline & Professionals $^{\mathrm{a}}$ & Managers ${ }^{\mathrm{b}}$ & Professionals & Managers & Professionals & Managers \\
\hline 1982 & 11,412 & 2,960 & 1,690 & 831 & 9,722 & 2,129 \\
\hline 1983 & 5613 & 2,088 & 1,627 & 914 & 3,986 & 1,174 \\
\hline 1984 & 4703 & 1,748 & 1,628 & 996 & 3,075 & 752 \\
\hline 1985 & 4851 & 1,677 & 1,757 & 928 & 3,094 & 749 \\
\hline 1986 & 6125 & 2,090 & 1,751 & 971 & 4,374 & 1,119 \\
\hline 1987 & 10,786 & 4,630 & 1,848 & 1,122 & 8,938 & 3,508 \\
\hline 1988 & 11,406 & 5,394 & 1,867 & 934 & 9,539 & 4,460 \\
\hline 1989 & 12,987 & 5,465 & 1,772 & 1,187 & 11,215 & 4,278 \\
\hline 1990 & 14,012 & 5,792 & 2,493 & 1,751 & 11,519 & 4,041 \\
\hline 1991 & 12,994 & 3,913 & 2,080 & 1,327 & 10,914 & 2,586 \\
\hline 1992 & 12,156 & 3,650 & 2,384 & 1,853 & 9,772 & 1,797 \\
\hline 1993 & 15,260 & 3,180 & 2,916 & 2,022 & 12,344 & 1,158 \\
\hline 1994 & 17,895 & 2,486 & 2,929 & 1,861 & 14,966 & 625 \\
\hline 1995 & 22,154 & 1,943 & 2,440 & 1,415 & 19,714 & 528 \\
\hline 1996 & 28,338 & 1,948 & 3,581 & 2,065 & 24,757 & -117 \\
\hline 1997 & 31,059 & 1,696 & 2,112 & 1,390 & 28,947 & 306 \\
\hline 1998 & 25,688 & 1,329 & 1,222 & 1,116 & 24,466 & 213 \\
\hline 1999 & 32,327 & 1,730 & 932 & 863 & 31,395 & 867 \\
\hline 2000 & 41,794 & 2,508 & 1,855 & 1,407 & 39,939 & 1,101 \\
\hline 2001 & 46,205 & 3,064 & 2,457 & 2,055 & 43,748 & 1,009 \\
\hline Total & 367,765 & 59,291 & 41,341 & 27008 & 326,424 & 32,283 \\
\hline
\end{tabular}

Sources: Immigrants to Canada: LIDS, 2004 and Out-Migration to US. NBER CPS Merged Outgoing Rotation Group (MORG) 2005.

Notes:

a. Professionals include engineers, natural scientists, university professors, teachers, nurses, physicians, medical technicians and 14 other professional groups. These are the intended occupations as stated upon arrival.

b. Managers are by self definition of immigrants upon arrival that they will be in supervisory capacity.

"Balance of Trade" prospective. In this case, immigration to Canada represents the number of permanent arrivals in the professional and managerial occupations in a particular year from all countries (including the U.S.) in columns (1) and (2) and the 
number of yearly leavers of Canadian-born residents to the United States in the same occupations in columns 3 and 4 . $^{2}$ Thus, this table mimics a triangular move (figure 3) which depicts immigrant movement into Canada from all sources with a subsequent and sometimes substantial movement of Canadian-born professionals and managers to the U.S.

The "Balance of Trade" in professionals is uniformly positive over the 1982-2001 period. Moreover, after 1986, Canada had a large "balance of trade" surplus vis a vis the U.S. in professionals. In fact, over the entire period Canada retained 87 per cent of its professional immigrants and gained 326,424 professionals during the 1982-2001 period.

The same is not true for managers since in many years in the mid 1980's and throughout the 1990's only small positive inflows of managers remained in Canada. In fact, Canada only retained 54 percent of its gross inflows of managers vis a vis emigration just to the United States. Moreover, Table 1 is unable to include on a yearly basis the substantial outflows of Canadian managers to Hong-Kong (see table 11) which would have made every year after 1996 a deficit year if I included these managerial émigrés to Hong Kong in table $1 .^{3}$ In addition table 1 does not include any foreign-born Canadian citizens residing in the United States. ${ }^{4}$

In sum, table 1 presents a conservative view of Canada's "balance of trade” in brains. Clearly, there was a substantial net inflow of professional immigrants to Canada but only a modest positive flow of managerial immigrants. ${ }^{5}$

\section{Balance of Payments in Brains}

But what is the economic value of the educational resources embedded in the immigrant inflows reported in table 1 ? Table 2 reports the information necessary to calculate a "balance of payments' concept for Canada and answer this query. Column one reports the gross inflow of permanent immigrants in these occupations circa 2001. For the nine occupational groups a total of 49,269 immigrants landed in Canada in 2001. If I follow Coulson and DeVoretz (1992) and value these immigrant inflows in terms of their educational replacement costs in Canada I can construct columns (2) to (9). In other

\footnotetext{
${ }^{2}$ According to Zhao et. al (2000) that $50 \%$ of permanent Canadian emigrants and 33\% of all temporary Canadian emigrants from Canada circa 1991-96 went to the United States.

${ }^{3}$ Hong-Kong return data is based on the 2000 Chinese Census and thus does not report yearly inflows but just a stock figure for 2000. At a minimum, 3,000 to 10,000 Canadian managerial émigrés left Canada for Hong-Kong in the 1990's ( see table 11).

${ }^{4}$ The data source used only allowed us to ask where were you born and if you were foreign-born. Thus, if you were Chinese-born but now a Canadian citizen residing in the United States our data source would not pick you up. An independent test using an alternative data source Homeland Security Yearbook of Immigration Statistics 2004 (http://uscis.gov/graphics/shared/statistics/yearbook/YrBko4lm.htm) indicates that table 1 underestimates the true emigration of Canadian residents by 28\% for the 1991-2000 period. In sum, using the Homeland Security Yearbook source we estimate that those Canadian emigrants to the United States who declared Canadian nationality equaled 191,987 while those who emigrants who stated they were Canadian-born equaled 137,563.

${ }^{5}$ Tables A-6A and A6B in the appendix report a detailed breakdown by occupations of the yearly immigrant inflow into Canada.
} 
words, assuming that Canada would have produced these graduates in the absence of these immigrants I can value the flow of these resources in terms of two Canadian educational cost concepts. Columns two and three respectively report the educational costs valued at what the Canadian student would have to pay (private total costs) and what Canadian society must pay (social total cost) for the required education to achieve they occupational status denoted in each row. In other words, the 2001 cost (in 1993 dollars) of acquiring an engineering degree for a student is $\mathbf{\$ 8 3 , 2 5 6}$ while society (student plus taxpayer costs) invests a total of $\$ 139,333$. The difference between the social and private costs is the inherent taxpayer subsidy to achieve an engineering degree and is reported in column 4. For any one occupation in 2001, columns seven and eight respectively report the total private and social costs to educate all immigrants who arrived in 2001 in that occupation.

An inspection of table 2 also reveals several trends under this evaluation technique. First, either under the private cost concept (column 2) or the social cost concept (column 3) there is a great deal of variance in the embodied educational costs by occupation. For example, nurses and medical technicians embody less than half the private or social educational resources as found in university professors or physicians. Secondly, the taxpayer subsidies inherent in this training also varies substantially across occupations indicating that the Canadian society gains differentially from importing for example, physicians versus nurses. Nonetheless, for this one year the gross value of the educational resources embodied in these professions amounted to $\$ 10.8$ billion with a $\$ 4.4$ billion of taxpayer subsidy. 
Table 2: Gross Value of Human Capital Flow in 2001 at Canadian Replacement Costs, by Occupations (1993 Canadian dollars) Occupations

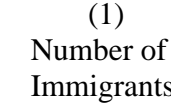

Immigrants

Costs per
Student
b

(2)

Private

Costs pe

Student $^{\mathrm{b}}$
Manager

Engineer

Natural Scientist

University Prof

Teacher $^{f}$

Physician

Nurse

Medical tech.

Other professional

TOTAL

Notes:

a Citizenship and Immigration Canada Landed Immigrant Data System, annual data. Thus, these are intended occupations.

c Social direct costs include private direct costs plus federal and provincial government expenditures per student per year.

d Private total costs per student equals direct costs plus foregone earnings for the relevant time spent in school. All occupations are four (4) years, except (5) years for engineers, six (6) years for scientists and teachers, and eight (8) years for both physicians and professors. Foregone earnings are defined as $\$ 9,248.21$ per year for those occupations requiring four years of schooling and 17,491.29 per year for those occupations that require a post B.A., B.B.A. or B.Sc. Earnings calculated from PUST 1991 Census.

e Social total costs equal direct costs plus foregone earnings.

f Based on a post-B.A. two-year education program. $\begin{array}{cl}(8)=(1) *(6) & (9)=(8)-(7) \\ \text { Social Total Cost } & \text { Taxpayers' }\end{array}$

for All Immigrants

Taxpayers
Subsidy for All

Immigrants

$\begin{array}{ll}\$ 550,576,288 & \$ 235,584,832 \\ \$ 3,877,898,310 & \$ 1,621,760,140 \\ \$ 784,850,838 & \$ 366,415,290 \\ \$ 112,637,607 & \$ 60,003,165 \\ \$ 186,925,095 & \$ 74,100,810 \\ \$ 262,740,702 & \$ 103,645,024 \\ \$ 73,446,017 & \$ 33,753,832 \\ \$ 253,798,651 & \$ 116,639,096 \\ \$ 4,672,938,185 & \$ 1,760,350,760 \\ \$ 10.776 \text { billion } & \$ 4.372 \text { billion }\end{array}$


Tables 3-A and 3-B report the embodied value of human capital in Canada's immigration inflows for 1980-2001 based on the social cost concept. Once again, there exists a great deal of variation across the selected occupations. Between 1980 and 1990 (table 3-A) no one profession dominated the immigrant flows in terms of the value of their educational inflows. Moreover, between 1980 and 1990 only $\$ 26.4$ billion dollars of educational resources flowed into Canada.

Table 3-A. Total Educational Values at Total Social Cost for All Immigrants to Canada by occupation, 1980-1990, in billion 1993 dollars

\begin{tabular}{|c|c|c|c|c|c|c|c|c|c|c|c|}
\hline & 1980 & 1981 & 1982 & 1983 & 1984 & 1985 & 1986 & 1987 & 1988 & 1989 & 1990 \\
\hline Managers & $\$ 0.47$ & $\$ 0.51$ & $\$ 0.53$ & $\$ 0.38$ & $\$ 0.31$ & $\$ 0.30$ & $\$ 0.38$ & $\$ 0.83$ & $\$ 0.97$ & $\$ 0.98$ & $\$ 1.04$ \\
\hline $\begin{array}{l}\text { Engir } \\
\text { Natu }\end{array}$ & $\$ 0.28$ & 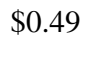 & 50 & 0.22 & & 6 & 1 & 8 & 6 & .44 & 0.51 \\
\hline $\begin{array}{l}\text { Scien } \\
\text { Univ }\end{array}$ & 16 & $\$ 0.18$ & 9 & 0.10 & 008 & 0 & 0.10 & $\$ 0.15$ & 16 & 21 & $\$ 0.21$ \\
\hline Profe & 0.18 & $\$ 0.12$ & $\$ 0.12$ & $\$ 0.10$ & $\$ 0.09$ & $\$ 0.11$ & $\$ 0.12$ & $\$ 0.13$ & $\$ 0.10$ & $\$ 0.15$ & $\$ 0.15$ \\
\hline Teachers & $\$ 0.19$ & $\$ 0.18$ & $\$ 0$ & $\$ 0.12$ & $\$ 0.11$ & $\$ 0.12$ & $\$ 0.14$ & $\$ 0.19$ & $\$ 0.21$ & $\$ 0.28$ & $\$ 0.33$ \\
\hline Physic & $\$ 0.20$ & $\$ 0.22$ & $\$ 0.24$ & $\$ 0.1$ & $\$ 0$. & $\$ 0.18$ & $\$ 0.22$ & $\$ 0.22$ & $\$ 0.19$ & $\$ 0.26$ & $\$ 0.26$ \\
\hline & $\$$ & $\$$ & & $\$$ & $\$ 0.05$ & $\$ 0.05$ & .07 & $\$ 0.12$ & 0.18 & 0.20 & $\$ 0.21$ \\
\hline $\begin{array}{l}\text { tech. } \\
\text { Other }\end{array}$ & $\$ 0.19$ & $\$ 0.16$ & $\$ 0.16$ & $\$ 0.10$ & $\$ 0.09$ & $\$ 0.09$ & $\$ 0.11$ & $\$ 0.18$ & $\$ 0.20$ & $\$ 0.26$ & $\$ 0.26$ \\
\hline al & $\$ 0.67$ & $\$$ & $\$ 0.90$ & $\$ 0.43$ & $\$ 0.36$ & $\$ 0.37$ & $\$ 0.48$ & $\$ 1.04$ & $\$ 1.11$ & $\$ 1.11$ & $\$ 1.18$ \\
\hline TOTAL & $\$ 2.44$ & $\$ 2.85$ & $\$ 3.11$ & $\$ 1.68$ & $\$ 1.43$ & $\$ 1.45$ & $\$ 1.82$ & $\$ 3.25$ & $\$ 3.47$ & $\$ 3.87$ & $\$ 4.16$ \\
\hline
\end{tabular}

Source: Author's computations. Immigrant inflows to Canada and outflows to USA used to construct this table appear in DeVoretz and Laryea (1998). In turn their numbers of Canadian émigrés to USA were provided by special tabulations provided by U.S. Dept. of Commerce, Naturalization Service.

Table 3-B illustrates dramatically different trends between 1991 and 2001. First, the total amount transferred during this period exceeded $\$ 64$ billion in educational resources with over $52 \%$ of this transfer occurring in the last four years of the study period. In addition, engineers and the collective category of 'other professionals' dominate these flows and by 2001 these two categories represent more than 80 per cent of the value of the inflow.

Table 3-b. Total Educational Values at Social Cost for All Immigrants to Canada by occupation, 19912001, in billion 1993 dollars

\begin{tabular}{|c|c|c|c|c|c|c|c|c|c|c|c|}
\hline & 1991 & 1992 & 1993 & 1994 & 1995 & 1996 & 1997 & 1998 & 1999 & 2000 & 2001 \\
\hline Managers & $\$ 0.70$ & $\$ 0.66$ & $\$ 0.57$ & $\$ 0.45$ & $\$ 0.35$ & $\$ 0.35$ & $\$ 0.31$ & $\$ 0.24$ & $\$ 0.31$ & $\$ 0.45$ & $\$ 0.55$ \\
\hline $\begin{array}{l}\text { Engineers } \\
\text { Natural }\end{array}$ & $\$ 0.48$ & $\$ 0.49$ & $\$ 0.81$ & $\$ 1.04$ & $\$ 1.38$ & $\$ 1.86$ & $\$ 2.20$ & $\$ 1.95$ & $\$ 2.64$ & $\$ 3.55$ & $\$ 3.88$ \\
\hline $\begin{array}{l}\text { Scientists } \\
\text { University }\end{array}$ & $\$ 0.21$ & $\$ 0.17$ & $\$ 0.21$ & $\$ 0.38$ & $\$ 0.54$ & $\$ 0.78$ & $\$ 0.83$ & $\$ 0.67$ & $\$ 0.79$ & $\$ 0.82$ & $\$ 0.79$ \\
\hline Professors & $\$ 0.20$ & $\$ 0.18$ & $\$ 0.17$ & $\$ 0.11$ & $\$ 0.10$ & $\$ 0.09$ & $\$ 0.07$ & $\$ 0.08$ & $\$ 0.08$ & $\$ 0.10$ & $\$ 0.11$ \\
\hline Teachers & $\$ 0.28$ & $\$ 0.23$ & $\$ 0.25$ & $\$ 0.19$ & $\$ 0.16$ & $\$ 0.18$ & $\$ 0.13$ & $\$ 0.11$ & $\$ 0.11$ & $\$ 0.16$ & $\$ 0.19$ \\
\hline Physician & $\$ 0.27$ & $\$ 0.25$ & $\$ 0.27$ & $\$ 0.21$ & $\$ 0.20$ & $\$ 0.23$ & $\$ 0.21$ & $\$ 0.18$ & $\$ 0.17$ & $\$ 0.23$ & $\$ 0.26$ \\
\hline $\begin{array}{l}\text { Nurses } \\
\text { Medical }\end{array}$ & $\$ 0.20$ & $\$ 0.17$ & $\$ 0.15$ & $\$ 0.14$ & $\$ 0.11$ & $\$ 0.07$ & $\$ 0.06$ & $\$ 0.04$ & $\$ 0.04$ & $\$ 0.06$ & $\$ 0.07$ \\
\hline $\begin{array}{l}\text { tech. } \\
\text { Other } \\
\text { profession } \\
\text { als }\end{array}$ & $\$ 0.22$ & $\$ 0.18$ & $\$ 0.18$ & $\$ 0.17$ & $\$ 0.18$ & $\$ 0.21$ & $\$ 0.21$ & $\$ 0.15$ & $\$ 0.17$ & $\$ 0.22$ & $\$ 0.25$ \\
\hline
\end{tabular}


$\begin{array}{llllllllllll}\text { TOTAL } & \$ 3.64 & \$ 3.40 & \$ 4.01 & \$ 4.44 & \$ 5.29 & \$ 6.69 & \$ 7.22 & \$ 5.99 & \$ 7.52 & \$ 9.74 & \$ 10.8\end{array}$

Source: See Table 3-A

In sum, although the 'balance of trade' portrays the dominance of the professional inflow of immigrants during this period it does not accurately portray the dominance in terms of educational resources of selected immigrant occupations, especially engineers in late 1990’s.

Table 4 completes my analysis by reproducing table 1 in value terms to report Canada's 'Balance of Payments in Brains' for the 1982-2001 period. ${ }^{6}$ It should be noted that this table is constructed under the assumption that immigrants to Canada and Canadian emigrants are perfect substitutes. The first two columns in table 4 represent the weighted (at social total costs) of the immigrant inflows of all professionals and managers who immigrated to Canada during the 1982-2001 period. The last two columns deduct for the outflows to the U.S. of Canadian-born residents in these two occupational categories. For managers, over $45 \%$ of the embodied value of the educational content of these immigrants from the rest of the world to Canada is lost to the U.S. alone. In fact, for the 1994-1999 period the net values are close to zero or negative since I have omitted the substantial additional outflows of Canadian managers to Hong-Kong and foreign-born Canadian citizens residing in the United States. The trends in professionally trained immigrants are very different since almost $90 \%$ of the educational value embodied in these immigrants remained in Canada over the study period.

Table 4. Balance of Payments in Human Capital Flows for 1982-2001 (1993 Canadian dollars)

\begin{tabular}{c|c|c|c|c|}
\hline & \multicolumn{2}{c}{ Gross Social Total Cost (millions) } & \multicolumn{2}{c}{ Net Social Total Cost (millions) } \\
& Professionals & Managers & Professionals & Managers \\
\cline { 2 - 6 } 1982 & $\$ 2,525.49$ & $\$ 304.30$ & $\$ 2,151.49$ & $\$ 218.87$ \\
1983 & $\$ 1,242.17$ & $\$ 214.65$ & $\$ 882.11$ & $\$ 120.69$ \\
1984 & $\$ 1,040.78$ & $\$ 179.70$ & $\$ 680.50$ & $\$ 77.31$ \\
1985 & $\$ 1,073.53$ & $\$ 172.40$ & $\$ 684.71$ & $\$ 77.00$ \\
1986 & $\$ 1,355.47$ & $\$ 214.86$ & $\$ 967.97$ & $\$ 115.04$ \\
1987 & $\$ 2,386.96$ & $\$ 475.98$ & $\$ 1,977.99$ & $\$ 360.64$ \\
1988 & $\$ 2,524.16$ & $\$ 554.52$ & $\$ 2,110.99$ & $\$ 458.51$ \\
1989 & $\$ 2,874.04$ & $\$ 561.82$ & $\$ 2,481.90$ & $\$ 439.80$ \\
1990 & $\$ 3,100.88$ & $\$ 595.44$ & $\$ 2,549.17$ & $\$ 415.43$ \\
1991 & $\$ 2,875.59$ & $\$ 402.27$ & $\$ 2,415.28$ & $\$ 265.85$ \\
1992 & $\$ 2,690.14$ & $\$ 375.23$ & $\$ 2,162.56$ & $\$ 184.74$ \\
1993 & $\$ 3,377.06$ & $\$ 326.92$ & $\$ 2,731.75$ & $\$ 119.05$ \\
1994 & $\$ 3,960.19$ & $\$ 255.57$ & $\$ 3,312.00$ & $\$ 64.25$ \\
1995 & $\$ 4,902.71$ & $\$ 199.75$ & $\$ 4,362.74$ & $\$ 54.28$ \\
1996 & $\$ 6,271.24$ & $\$ 200.26$ & $\$ 5,478.76$ & $-\$ 12.03$ \\
1997 & $\$ 6,873.40$ & $\$ 174.36$ & $\$ 6,406.01$ & $\$ 31.46$ \\
1998 & $\$ 5,684.79$ & $\$ 136.63$ & $\$ 5,414.36$ & $\$ 21.90$ \\
1999 & $\$ 7,154.01$ & $\$ 177.85$ & $\$ 6,947.76$ & $\$ 89.13$ \\
2000 & $\$ 9,249.07$ & $\$ 257.83$ & $\$ 8,838.56$ & $\$ 113.19$ \\
& & & & \\
\hline
\end{tabular}

\footnotetext{
${ }^{6}$ The calculations embedded in table 4 assume that immigrants and emigrants in the same profession are perfect substitutes.
} 


\begin{tabular}{c|cccc}
2001 & $\$ 10,225.24$ & $\$ 314.99$ & $\$ 9,681.50$ & $\$ 103.73$ \\
\hline Total & $\$ 81,386.94$ & $\$ 6,095.35$ & $\$ 72,238.12$ & $\$ 3,318.82$ \\
\hline
\end{tabular}

Notes: a. Professionals and Managers defined per Table 1.

In sum, under either the 'balance of trade' or balance of payments' concepts two overarching trends appear. Canada was a large net importer of professional skills, especially engineers in the 1990's while managers were difficult to retain. ${ }^{7}$

We now turn to the underlying economic forces which rationalized Canada's vast recruitment of professionals across a changing occupational composition.

\section{Part III. Labour Markets and Historical Immigration Entry Criteria}

'Tap On - Tap Off' entry criterion: 1976-1988

Canada's historical policy of importing immigrants to foster economic growth has met with criticism from many fronts over the last ten years. Specifically many critics including Jeffrey Reitz (2005) have argued that since the mid 1990's many forces including a lack of skills recognition have led to a deskilling of the imported highly skilled immigrants and resulted in a deadweight loss to the Canadian economy of 2 billion dollars annually. Other critics, including the Conference Board of Canada have echoed these concerns and the media have documented numerous cases of putatively highly skilled immigrants working at low paying unskilled jobs. In fact, Chris Worswick (2004) has analyzed the generally poor economic performance of educated immigrants in the early $21^{\text {st }}$ century and concluded that a drastic change in immigration policy is needed. First, he argues that there should be a temporary halt in immigration flows and next he argues that Canada should return to the "tap on - tap off” policy of the 1980's.

The purpose of this section of my essay is to argue that the 1990's represented a key watershed in Canadian immigration policy with respect to the recruitment of the highly skilled. Canada's skilled recruitment policy changed from a "tap on - tap off” policy circa 1976-1986 to a uniformly high intake level coupled with a "fifty-fifty" entry criteria between 1988 and the present (DeVoretz, 2006a). In other words, the 'fifty-fifty' immigration policy of the 1990's implied that the admission of one economic immigrant allowed the possible admission of one extended family member or refugee. This policy change from a "tap - on tap off" policy to a "fifty-fifty" admission's regime represented a fundamental shift in the viewpoint of Citizenship and Immigration Canada (CIC) on how immigrants integrate into Canada’s labour market.

\footnotetext{
${ }^{7}$ Although the cited tables do not include Chinese skilled emigration from Canada to Hong Kong separate evidence reported in DeVoretz and Zhang(2004) states that less than 20 percent of 70,000 employed Canadian émigrés to Hong Kong were classified as professional in the 2000 Chinese Census. Thus, given the 324,000 net inflow of professionally trained immigrants to Canada for the 1981-2001 period as cited in Table 3 above the net inflow of professional conclusion stands. In fact this number would have been reduced at maximum by 20,000 from the post 1997 emigration of Chinese professionals from Canada. ${ }^{8}$ See D. J. DeVoretz (1995) who first argued that in the 1980's the "tap on - tap off” policy resulted in immigrant fluctuations ranging from a high of 200,000 to a low of 80,000 over the decade.
} 
The "tap on - tap off" policy circa 1976-1986 was embedded in the creation of the "points system" which first appeared in 1967. It was argued by DeVoretz and Maki (1983) that the first "points system" between 1967-1978 was essentially a test for human capital attributes as opposed to a manpower policy which underlay the "tap on - tap off" policy of the 1976-1988 period (see column 1 table 1). The human capital admissions policy circa 1967-78 contained many salient features. First, the total pass mark was low during this period, namely 50 points out of a possible maximum of 100 points (see table 4). Next, all the necessary 50 marks for admission could be potentially gained without a labour market test from education, age, language and personal suitability criteria. Finally, and most importantly, there existed no yearly immigrant target level circa 1967-1976, thus, entry levels were byproducts of the number of immigrants that applied and the number that Canada could process.

After 1978 the human capital regime was replaced by a manpower vacancy criterion which implied a 'tap on - tap off' policy. At its apex in 1986 the 'tap on - tap off' policy used a labour vacancy criterion were a mixture of experience, vocational preparation, occupational demand, arranged employment and a levels control criteria accounted for 52 out of the possible 100 points (see table 5). Clearly by 1986 entry via the economic or selected worker category gateway could not occur with just human capital attributes but the applicant had to also satisfy immigration officials that a job vacancy existed and that he/she could fill it.

Table 5. Canada's Points System over Time: $1967-2002^{9}$

\begin{tabular}{lrrrrrrrr}
\hline & 1967 & 1974 & 1978 & 1986 & 1993 & 1996 & \multicolumn{1}{c}{ post } & 2002 \\
\cline { 2 - 8 } & 20 & 20 & 12 & 12 & 14 & 21 & 16 & 25 \\
Education & & & 8 & 8 & 8 & 9 & 8 & 21 \\
Spperience & 10 & 10 & 15 & 15 & 16 & & 18 & \\
preparation vocational & 15 & 15 & 10 & 10 & 10 & & 10 & \\
Occupational demand & & & & & & 10 & & \\
Labour market balance & 10 & 10 & 10 & 10 & 10 & 13 & 10 & 10 \\
Age & 10 & 10 & 10 & 10 & 10 & 4 & 10 & 10 \\
Arranged employment or & 10 & 10 & 15 & 15 & 14 & 21 & 15 & 24 \\
designated occupation & 15 & 15 & 10 & 10 & 10 & 17 & 10 & 10 \\
Language & & & 10 & 10 & 8 & & & \\
Personal suitability & & & & & & & 8 & \\
Levels & 5 & 5 & & & & 5 & 5 & \\
Demographic & 100 & 100 & 100 & 100 & 100 & 100 & 110 & 100 \\
Relative & 50 & 50 & 50 & 70 & 67 & 65 & 70 & 75 \\
Designation & & & & & & &
\end{tabular}

Source Yan Shi (2004)

\footnotetext{
${ }^{9}$ Quebec has a separate selection grid.
} 
Two additional screening devices were put into place in the 1980's to further ensure that the economic or independent immigrant class met Canada's manpower needs under a 'tap on - tap off' policy. Of the now 70 points required for admission in the 1980's some occupational points were a necessary, but not a sufficient condition for entry in the independent class. If the potential immigrant's designated occupation was assigned zero points for labour demand by policy makers, then, regardless of the total number of points earned by the immigrant from their human capital characteristics the immigrant would not be admitted. ${ }^{10}$ In the 1982-1985 period these labour market restrictions became even more stringent as previously certified and arranged employment was required before entry was permitted in the economic class.

Table 6. Immigrant Arrivals by Class: 1980-2001

\begin{tabular}{|c|c|c|c|c|c|}
\hline \multirow[b]{2}{*}{$\begin{array}{l}\text { Year of } \\
\text { Landing }\end{array}$} & \multirow[b]{2}{*}{$\begin{array}{l}\text { Total } \\
(1)\end{array}$} & \multicolumn{3}{|c|}{ Immigrant Class } & \multirow{2}{*}{$\begin{array}{c}\% \\
\text { Economic } \\
(4) /(1)= \\
(5)\end{array}$} \\
\hline & & $\begin{array}{l}\text { Refugee } \\
\text { (2) }\end{array}$ & $\begin{array}{l}\text { Family } \\
\text { (3) }\end{array}$ & $\begin{array}{l}\text { Economic } \\
\text { (4) }\end{array}$ & \\
\hline 1980 & 143,134 & 43,860 & 49,180 & 36,670 & 0.256692 \\
\hline 1981 & 128,641 & 18,588 & 50,204 & 42,977 & 0.334944 \\
\hline 1982 & 121,177 & 17,518 & 49,859 & 40,048 & 0.332029 \\
\hline 1983 & 89,188 & 13,998 & 48,701 & 19,408 & 0.21901 \\
\hline 1984 & 88,273 & 15,377 & 43,818 & 18,605 & 0.213272 \\
\hline 1985 & 84,333 & 16,770 & 38,528 & 19,532 & 0.235831 \\
\hline 1986 & 99,329 & 19,198 & 42,236 & 30,169 & 0.309397 \\
\hline 1987 & 152,002 & 21,468 & 53,568 & 62,018 & 0.414795 \\
\hline 1988 & 161,502 & 26,737 & 51,165 & 64,922 & 0.409605 \\
\hline 1989 & 191,502 & 36,857 & 60,630 & 69,011 & 0.366791 \\
\hline 1990 & 216,402 & 40,233 & 74,069 & 72,903 & 0.342253 \\
\hline 1991 & 232,750 & 54,053 & 86,894 & 65,247 & 0.284062 \\
\hline 1992 & 254,816 & 52,350 & 100,668 & 76,225 & 0.304231 \\
\hline 1993 & 256,728 & 30,632 & 112,579 & 79,725 & 0.316126 \\
\hline 1994 & 224,373 & 20,455 & 94,093 & 69,908 & 0.317043 \\
\hline 1995 & 212,866 & 28,544 & 77,325 & 71,914 & 0.342895 \\
\hline 1996 & 226,050 & 32,193 & 68,296 & 91,543 & 0.411008 \\
\hline 1997 & 216,030 & 27,662 & 59,893 & 100,162 & 0.480204 \\
\hline 1998 & 174,172 & 25,375 & 50,799 & 80,162 & 0.490449 \\
\hline 1999 & 189,921 & 25,415 & 55,248 & 90,733 & 0.494976 \\
\hline 2000 & 227,312 & 30,532 & 60,541 & 113,801 & 0.511806 \\
\hline 2001 & 250,346 & 28,104 & 66,641 & 130,034 & 0.526684 \\
\hline
\end{tabular}

Source: Landed Immigrant Data System (LIDS), Citizenship and Immigration Canada. Notes: Refugee Class includes: Convention Refugee Class, Designated Class, Nominated (Old Act 1952), PDRCC Class, Dependants of a CR8 Refugee, DROC Class, Source Country, Asylum Country; Economic Class includes: Entrepreneur Class, Self-Employed Class, Independents and Entrepreneurs (Old Act 1952), Other Independent Class (Skilled Workers), Investor Class; Other (not shown in the table) classes include: Retired Class, Assisted Relative Class, Live-In Caregiver Class, Child to be Adopted, Sponsored (Old Act 1952).

\footnotetext{
10 The occupational groups were defined to a three digit occupational code.
} 
Finally, this "tap on - tap off” was coupled with an explicit yearly quota which by law had to be tabled in the House of Commons in the previous calendar year. This quota resulted in a bizarre restriction on the number of selected economic immigrants actually admitted. In fact, given sufficient Canadian emigration in the 1981 to 1986 period the number of selected immigrants was a residual of the total yearly quota that could result in a meager net flow of economic immigrants (see table 6 column 5). ${ }^{11}$ How did this come about? First, the yearly target was set and then the number of immigrants anticipated under the family class for the next year was deducted from this target. Next, a predetermined number of refugees were deducted from this net target figure and then the residual was assigned to the independent/economic immigrant class. ${ }^{12}$ In a year when the government set the yearly target below 100,000 the number of immigrants in the residual economic class was nil if Canadian emigration was sufficiently large. ${ }^{13}$

In sum, it could be argued that Canada's post 1976 to pre 1990 immigration policy with respect to independent or economic immigrants implied a 'job vacancy' criterion to earn admission. And as noted this ‘job vacancy' model had in fact replaced a human capital model which was active prior to 1976 according to DeVoretz and Maki (1983).This "tap on-tap-off” policy ultimately led to a near zero net economic immigrant inflows in the mid 1980’s.

\section{Post 1990 Entry Criterion: Cinquante-Cinquante}

The challenge in this section is to characterize the entry criteria in the 1990's and to provide a test of the efficacy of this model since evidence cited above purports to show that Canada failed to select the quantity and quality which could successfully integrate into the labour force after 1990.

The late 1980's witnessed a resurrection in both the total number of immigrants and those who were selected as economic immigrants. Under the then Conservative government the political view of the immigrant labour market moved away from both the 'tap on - tap off' and human capital views that had prevailed under successive governments since the mid 1960's. A new entry criterion emerged in the 1990's which allowed entry to a growing absolute number of economic immigrants who possessed financial capital. After 1986, entry was not subject to a labour market vacancy test, but rather entry criteria reflected individual human capital endowments and most importantly past labour market experience (see table 5).

\footnotetext{
11 In the 1980's it was estimated that 50,000 or more immigrants left Canada yearly.

12 The previously constant number of refugees began to fluctuate widely by the mid 1980's and made refugee forecasts unreliable. See DeVoretz and Pivnenko (2004) for a complete analysis of refugee flows during this period.

${ }^{13}$ For example, in the 1983-1985 period the yearly target was less than 100,000 immigrants and the independent/economic class constituted less than $23 \%$ of the yearly target or 19,000 economic immigrants. Clearly with an historical 30\% emigration rate more than 19,000 economic immigrants could have left during this period and would have negated these yearly inflows.
} 
How these entry criteria actually were applied will be assessed in detail below. At this point, I would like to develop the overall economic philosophy which drove immigrant admissions after 1990 to the present. The Conservative government and the then Minister of Employment and Immigration Barbara McDougall in the early 1990's once again returned to Canada's historical position that economic immigrants could act as an engine of economic growth. She specifically eschewed the view that Canada's labour market consisted of a 'lump of jobs' such that one more employed immigrant implied one less job for resident Canadians. This 'lump of jobs' concept was the contentious cornerstone of the 'tap on - tap off' policy which reigned during the 1976-1988 period. It was felt by the late 1980's that if you could select economic immigrants with complementary inputs, namely financial and human capital, then economic immigrants could create jobs for both themselves and potentially for resident Canadian-born workers. Akbari and DeVoretz (1988) had provided limited empirical evidence to weakly support this view when they found that immigrants on balance created as many jobs as they took in the 1980's. ${ }^{14}$

During the 1980s' both the Liberal and Conservative governments introduced a series of new entry categories for potential economic immigrants which if exploited could possibly insure a growing labour market demand with immigrant admissions. Thus, the entrepreneurial and investment immigrant entry categories were devised in the 1980's and refined in the 1990's to attract putative entrepreneurial immigrants (DeVoretz, 1996). ${ }^{15}$ In addition, particular attention was paid to recruiting through the normal 'points system' large number of managers from Hong-Kong and Taiwan. Although this group had to acquire 67-70 points for entry there was no explicit investment or employment conditions attached. It was hoped that their managerial backgrounds would result in increased employment opportunities as they integrated into existing Canadian firms. Finally, engineers were targeted for admission under the supposition that the IT boom would continue throughout the early $21^{\text {st }}$ century and that an engineering 'shortfall' would occur. ${ }^{16}$ This post 1988 recruitment policy all assumed that the targeted economic immigrants would either provide financial capital (investors) or human capital (managers and engineers) such as their entrance into their respective labour market would cause a demand shift for their services. In turn, it was hoped that this would result in an increased demand for resident labour or a rise in wages or both. The object of a later section of my essay will be to test and confirm or reject this view for selected immigrant occupations.

This radical new view that immigrants could be chosen to increase Canadian employment opportunities was theoretically well grounded but faced many political and institutional difficulties. The political difficulty arose from the explicit existence of the family

\footnotetext{
${ }^{14}$ Of course the details of the study were more complex. Labour substitution by immigrants occurred in immigrant intensive labour markets which contained at least 30 per cent or more foreigners in their labour market. The rest of the economy which was highly unionized at the time was largely insulated from the small number of economic immigrants which arrived in the 1980's. Hence the neutral finding on immigrant job displacement.

${ }^{15}$ The entrepreneurial entry category required that the prospective immigrant provide employment for himself and at least, one resident Canadian to insure permanent residence status. The investor class entry gate required initially a \$350,000 investment in selected categories but required no job creation.

${ }^{16}$ Dire predictions forecasted a software engineering shortfall in Canada of between 40 to 100 thousand engineers. This of course proved erroneous.
} 
reunification provision in the 1976 Immigration Act which awarded substantial sponsorship entitlements to a successful economic applicant. In short, the spouse and minor children were allowed immediate entry with the successful applicant. In addition, parents and grandparents would also be granted entry after a 'means test' was applied to the original principal applicant and conditions on the use of social services were placed on the sponsored relatives. ${ }^{17}$ Given that both spouses in the initially successful economic immigrant household could sponsor their relatives, the logic of the sponsorship provision implied that each successful economic immigrant created four or more potential family class entrants. 18

This potential multiplier effect created a substantial political barrier to allow the admission of a sufficiently large portion of economic immigrants. Thus, a crucial policy restraint was added in 1995 under Sergio Marchi that, regardless of the total yearly target selected, at least fifty percent of the admissions were required to be economic immigrants. To wit, the cinquante cinquante provision, which allowed in any one year fifty percent economic and fifty percent family and refugee entrants was devised in 1995 and still holds circa 2005. This "cinquante cinquante" policy insured that two crucial conditions were met. First, that the growing family class would be capped in any one year and that potentially a sufficiently large number of economic immigrants would enter Canada to create the necessary jobs envisioned. ${ }^{19}$

There is of course one crucial restraint in this entire philosophy. In any one year Canada had to pick a realistic overall immigration target such that 50 per cent of the required economic applicants could be recruited. Moreover, the "tap on - tap off” policy of the 1980s' could not be resorted to if the recruited economic immigrants fell since it was no longer politically feasible. In fact by the 1990's approximately 100,000 family class members had to be admitted to respond to the requests of a growing and politically powerful immigrant class. In addition Canada had a yearly implied quota of around 25,000 refugees according to DeVoretz and Pivnenko (2004). Given this base requirement to admit 125,000 non economic immigrants then 125,000 economic immigrants had to be recruited yearly to satisfy the "cinquante-cinquante' criterion. This goal was not always met since appropriate economic immigrants were unavailable or difficult to process and the original overall target was not met. It also must be remembered that the government defined the economic class of immigrants to include independently assessed immigrants, investors and their spouses, thus vastly overstating the size of the economic class. In fact as table 5 shows that the economic class admissions (including immediate family) fluctuated between $25 \%$ and 52\% between

\footnotetext{
17 The current means test requires that the sponsoring household's income, net of any government transfers exceed the local poverty level or the Low Income Cutoff (LICO) line as reported by Statistics Canada. This is a substantial barrier since circa 2005 the required household income before sponsorship exceeded $\$ 45,000$ in Vancouver for an immigrant sponsoring family with two children.

${ }^{18}$ Actually, the number of potential sponsorships per household was potentially much larger. If sponsored parents brought any remaining minor siblings then in turn these siblings when mature could marry foreigners who, in turn, could sponsor further relatives. Thus, the long run multiplier effect under this scenario is very large but undefined.

${ }^{19}$ The weak economic performance of the family class is documented in DeVoretz and Pivnenko (2004) and justifies the need for a large economic class.
} 
1981 and 2001. Thus, Canada in reality only loosely approached the 50 percent criterion after 1996.

In sum, the post-1990 immigrant admission policy was predicated on admitting a sufficient number of highly qualified immigrants to insure a growing excess labour demand in their particular occupation which would either raise the wage rates of resident labour market members or increase their employment opportunities. Below I present a theoretical construct in figure 2 which formalizes my main arguments and allows me to deduce a testable set of hypotheses to confirm or reject the success or failure of Canada's post-1990 immigration policy of recruiting immigrants to induce excess labour demand and foster economic growth.

\section{Model}

This model will focus on Canada's demand for highly trained immigrants in selected occupations. The proposed excess demand is recursive in nature and assumes an infinitely elastic supply curve of highly skilled immigrants. I have argued elsewhere that there exists an infinite supply (or at least a large one relative to Canada's demand) of technically trained immigrants for Canada at the prevailing wage. ${ }^{20}$ Hence, changes in Canada's excess labour demand in a particular labour market will determine the placement of the immigrant demand curve and determine the next period's equilibrium number of immigrants admissions.

Figure 1: Immigrant Excess Demand



\footnotetext{
${ }^{20}$ Elsewhere I have argued that this infinite supply argument held in general for Canada in this period only because China, more specifically the PRC, lifted its restriction on the emigration of highly skilled Chinese in 1995 (DeVoretz, 2003).
} 
Figure 1 illustrates the comparative statics of the proposed dynamic shortages model in an immigrant demand context. In any one period $(\mathrm{t}-1)$ given a real income level of $\left(\mathrm{Y}_{1}\right)$ there exists a domestic supply of (jth) type skilled labour equal to (oa) which results in a positive excess demand for skilled labour equal to (ab). This excess demand could be filled by more domestic graduates in period (t) equal to (ae) as the (jth) occupational income rises to $\mathrm{Y}_{2}$ and with an immigrant flow of (ef) given this income of $\mathrm{Y}_{2}$. On the other hand, with no increase in either the income level $\left(\mathrm{Y}_{1}\right)$ or the domestic supply of labour (oa) in the (jth) occupation, the gap could be totally filled by (a-b) immigrants.

Further I argue that policy makers attempt to forecast the yearly excess demand (ab) at income $\mathrm{Y}_{1}$ or (ef) at income $\mathrm{Y}_{2}$. My arguments above suggest that a 'tap on - tap off' policy would lead to a relatively large (ab) immigrant flow to maintain the prevailing income level of $\mathrm{Y}_{1}$. On the other hand, in the post 1990 world immigrant policy makers would admit (ef) immigrants to insure (ae) growth in domestic employment and a rise in income to $\mathrm{Y}_{2}$.

The above arguments lead me directly to the following Canadian immigrant demand specification for the jth highly skilled immigrant:

$I_{i j, t}=f\left(G_{j, t-2}, I_{i j, t-1,}\left(Y_{j, t-1}-Y_{j, t-2}\right)\right)$

In short, the absolute number of immigrants admitted to Canada from an (ith) country with the (jth) type of skills in period $(\mathrm{t})$ or $\mathrm{I}_{\mathrm{ij}, \mathrm{t}}$ depends on three exogenous variables which I outline below.

The lagging process built into the model is crucial since as I noted earlier policy makers must by law forecast their desired immigration flows 12 to 18 months in advance of the actual dates of admission. Hence the domestic supply variable or the increased supply of highly skilled graduates in the (jth) occupation is lagged two periods (i.e. $G_{j, t-2}$ ) This lag would reflect the latest graduate information available to policy makers when the immigration target was set in period (t-1).

The income variable requires a detailed explanation. The income term is a much debated variable in immigration studies. One view suggests that the income difference over time in the destination country's income is a proxy for the growth in excess demand in the destination country's labour market and hence relevant to this study. We include the relevant Canadian change in occupational income under this rationale. Again we note due to legislative time lags, policy makers only have at their disposal the change in lagged income in periods ( $\mathrm{t}-1)$ and $(\mathrm{t}-2)$ to measure potential excess demand for labour in the (jth) occupation. Hence, it is argued, as lagged income in the (jth) occupation rises, policy makers infer that ceteris paribus excess demand in that occupation has grown and immigration levels should rise.

Finally, I introduce $\mathrm{I}_{\mathrm{ij}, \mathrm{t}-1}$ as a statement that if policy makers lack income or graduate supply information they will simply make contemporary immigration levels a proportion of last years immigrant levels. 


\section{Data}

The data sources and definitions are contained in Appendix table A-1. Table 7 reports the admission trends in the selected professions that I will analyze with my proposed demand model. Several patterns emerge from an inspection of table 7. First, for these seven selected occupations, the grand total of admissions for the period 1980 to 2001 was large $(313,766)$ with the bulk admitted after 1988. Furthermore, it is possible to see epochal trends as Canada's policy makers switched from one occupation to another. Between 1987 and 1997 for example, 40,000 immigrants in managerial occupations were admitted which simply reflected the emigrant movement from Hong-Kong and Taiwan during this period.

Table 7. Sample of Immigrant Arrivals by Selected Occupations: 1980-2001

\begin{tabular}{|c|c|c|c|c|c|c|c|}
\hline & $\begin{array}{l}\text { Managerial and } \\
\text { Administrative }\end{array}$ & $\begin{array}{l}\text { Scientists } \\
\text { (Natural } \\
\text { and Life } \\
\text { Sciences) } \\
\end{array}$ & $\begin{array}{l}\text { Engineers } \\
\text { and } \\
\text { Architects } \\
\end{array}$ & $\begin{array}{l}\text { Nursing, } \\
\text { Therapy } \\
\text { and Related } \\
\text { Assisting } \\
\text { Occupations } \\
\end{array}$ & $\begin{array}{l}\text { Teaching } \\
\text { Occupations } \\
\end{array}$ & $\begin{array}{l}\text { Professional } \\
\text { Occupations } \\
\text { in Art and } \\
\text { Culture } \\
\end{array}$ & $\begin{array}{l}\text { Professional } \\
\text { Occupations } \\
\text { in Social } \\
\text { Science, } \\
\text { Government } \\
\text { Services and } \\
\text { Religion } \\
\end{array}$ \\
\hline 1980 & 2,599 & 577 & 1,315 & 1,048 & 1,592 & 853 & 661 \\
\hline 1981 & 2,848 & 638 & 2,249 & 1,423 & 1,341 & 843 & 732 \\
\hline 1982 & 2,960 & 704 & 2,795 & 1,425 & 1,421 & 822 & 805 \\
\hline 1983 & 2,088 & 367 & 1,056 & 543 & 1,020 & 517 & 665 \\
\hline 1984 & 1,748 & 289 & 754 & 474 & 989 & 466 & 566 \\
\hline 1985 & 1,677 & 310 & 743 & 513 & 1,092 & 495 & 526 \\
\hline 1986 & 2,090 & 353 & 980 & 643 & 1,159 & 562 & 668 \\
\hline 1987 & 4,631 & 542 & 1,826 & 1,112 & 1,523 & 784 & 1072 \\
\hline 1988 & 5,395 & 590 & 1,740 & 1,403 & 1,390 & 839 & 1082 \\
\hline 1989 & 5,471 & 759 & 2,058 & 1,636 & 1,863 & 1069 & 1094 \\
\hline 1990 & 5,794 & 773 & 2,410 & 1,807 & 2,216 & 1107 & 1181 \\
\hline 1991 & 3,916 & 765 & 2,296 & 1,617 & 2,309 & 1048 & 1143 \\
\hline 1992 & 3,652 & 618 & 2,323 & 1,546 & 1,792 & 971 & 1073 \\
\hline 1993 & 3,180 & 780 & 3,746 & 1,413 & 1,896 & 1254 & 1243 \\
\hline 1994 & 2,489 & 1,378 & 4,722 & 1,388 & 1,445 & 1330 & 1479 \\
\hline 1995 & 1,943 & 1,971 & 6,262 & 1,226 & 1,365 & 1442 & 1738 \\
\hline 1996 & 1,950 & 2,805 & 8,372 & 991 & 1,404 & 1846 & 2014 \\
\hline 1997 & 1,697 & 2,993 & 9,873 & 1,028 & 1,107 & 1866 & 2004 \\
\hline 1998 & 1,334 & 2,478 & 8,688 & 805 & 987 & 1560 & 1581 \\
\hline 1999 & 1,732 & 3,011 & 11,726 & 830 & 1,076 & 1655 & 1837 \\
\hline 2000 & 2,510 & 3,279 & 15,708 & 1,111 & 1,475 & 2027 & 2241 \\
\hline 2001 & 3,065 & 3,292 & 17,161 & 1,303 & 1,689 & 2078 & 2647 \\
\hline \multirow[t]{2}{*}{ Total } & \multirow[t]{2}{*}{64,769} & \multirow[t]{2}{*}{29,272} & \multirow[t]{2}{*}{108,803} & \multirow[t]{2}{*}{25,285} & 32,151 & 25,434 & 28,052 \\
\hline & & & & & & Grand Total & 313,766 \\
\hline
\end{tabular}

Source: LIDS 2002

Between 1995-2001 scientists and engineers begin to dominate immigrant inflows with respectively totals of 19,829 and 77,790 immigrant arrivals. In other words, 72 (67.7\%) 
per cent of all engineers (scientists) who arrived during the 1980-2001 period arrived in the last seven years of the study period. This again highlights the switch in occupational composition of immigrants over the decade as the presumed private sector's demand grew. What is even more interesting to note is the collapse in the immigrant admissions to the public sector in the 1990's with teacher and nursing immigrant admissions averaging around 1,000 yearly. Thus, the 1990's began with substantial managerial admissions and closed with large admissions of scientists and engineers. But, was the policy response consistent with a growing labour demand in Canada or simply the result of supply changes in China and India?

Results

Below we report several versions of our basic model and provide interpretations of the results when appropriate.

Table 8 reports the results for my model stripped to its basic form where immigration levels today simply depend on past immigration levels. In other words, this model argues that policy makers ignored other variables and made a naïve forecast of contemporary demand for immigrants as a proportion of last years immigrant flow. This modification leads to a distributed lag version of my model which permits either an explosive, decaying or constant immigrant demand. The system is driven by $\lambda^{\mathrm{h}}$ which is the distributed lagged multiplier which can exceed unity if $\lambda^{\mathrm{h}}$ exceeds unity and under this condition lead to an explosive system where any positive $\mathrm{I}_{\mathrm{ij}, \mathrm{t}-\mathrm{k}}$ accelerates future immigration admissions by policy makers. ${ }^{21}$ If $\lambda$ is positive, but is less than unity than the system would decay as policy makers respond less and less to changes in past immigration levels $\left(\mathrm{I}_{\mathrm{ij}, \mathrm{t}-\mathrm{k}}\right)$. Of course if $\lambda^{\mathrm{h}}=0$ then no relationship would exist between immigration today and yesterday as policy makers ignore the change in the last period's immigrations levels. Finally, if $\lambda^{\mathrm{h}}<0$ then past immigration (i.e. $\mathrm{I}_{\mathrm{ij}, \mathrm{t}-\mathrm{k}}$ ) is perceived by policy makers as competition in the domestic labour market for in the (jth) occupation and less immigrants are admitted in the each successive period.

Table 8: Distributed lag model: $\mathrm{I}_{\mathrm{ij}, \mathrm{t}}=\lambda^{\mathrm{k}}\left(\mathrm{I}_{\mathrm{ij}, \mathrm{t}-1 \ldots \ldots .} \mathrm{I}_{\mathrm{ij}, \mathrm{t}-\mathrm{n} .}\right)$




Source: Author's calculations

Table 8 reports the results for this distributed lagged model. The estimated coefficient for $\lambda$ equals .46 and is significant. This positive but less than unity value for $\lambda^{\mathrm{h}}$ indicates that the system is decaying. In other words, contemporary immigration levels $\left(\mathrm{I}_{\mathrm{ij}, \mathrm{t}}\right)$ are only partially conditioned (.46) on past levels of immigration ( $\left.\mathrm{I}_{\mathrm{ij}, \mathrm{t}-1}\right)$. Moreover, given the estimated value of $\lambda^{\mathrm{h}}(.46)$ the mean calculated lag between when policy makers set contemporary immigration and past immigration is about 10.2 months. ${ }^{22}$ This is a powerful result since it accords with the Canadian institutional requirements that immigration levels must be announced one year in advance which implies that if policy makers do partially use recent immigration levels to dictate future levels that the lag would be approximately one year.

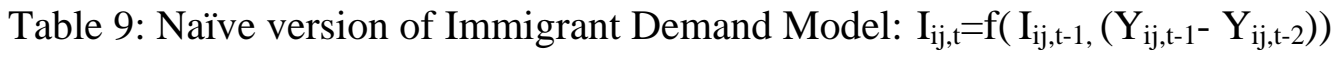

\begin{tabular}{|c|c|c|c|c|c|c|}
\hline $\begin{array}{l}\text { VARIABLE } \\
\text { NAME }\end{array}$ & $\begin{array}{l}\text { ESTIMATED } \\
\text { COEFFICIEN }\end{array}$ & $\begin{array}{l}\text { STANDARD } \\
\text { ERROR }\end{array}$ & T-RATIO & P-VALUE & $\begin{array}{l}\text { STANDARD- } \\
\text { COEFF. }\end{array}$ & $\begin{array}{l}\text { ELASTICITY } \\
\text { AT MEANS }\end{array}$ \\
\hline & 0.47246 & $0.5920 \mathrm{E}-01$ & 7.981 & 0.000 & 0.4750 & 0.4679 \\
\hline$Y_{\mathrm{ij}, \mathrm{t}-1^{-}} \mathrm{Y}_{\mathrm{i}}$ & $0.19926 \mathrm{E}-01$ & $0.7152 \mathrm{E}-02$ & 2.786 & 0.006 & 0.0801 & 0.0016 \\
\hline ONSTANT & Г 692.61 & 95.42 & 7.259 & 0.000 & 0.0000 & 0.3996 \\
\hline
\end{tabular}

$\mathrm{N}=119 \mathrm{R}^{2}=.66$

Source: Author's calculations

Table 9 expands on the results of table 8 by arguing that in addition to last year's immigration levels changes in the earnings $\left(\mathrm{Y}_{\mathrm{ij}, \mathrm{t}-\mathrm{1}^{-}} \mathrm{Y}_{\mathrm{ij}, \mathrm{t}-2}\right)$ in the relevant occupation will dictate the demand for a particular type of professionally trained immigrant. The model proves stable and the hypothesized positive sign between immigration levels and the change in earnings and past immigration levels is maintained. Increased earnings $\left(\mathrm{Y}_{\mathrm{ij}, \mathrm{t}-\mathrm{1}^{-}}\right.$ $\mathrm{Y}_{\mathrm{ij}, \mathrm{t}-\mathrm{2}}$ ) in the relevant profession leads to a modest increase (.02) in immigrant demand in that occupation. Again, this system is not explosive since lambda is less than unity (.47) and the mean period lag remains at 10.5 months.

Table 10 reports the results of the complete model which now includes a lagged (two period) graduation level variable in the relevant immigrant occupation. The inclusion of $\mathrm{G}_{\mathrm{ij}, \mathrm{t}-2}$ does not yield a significant coefficient and the now insignificant income variable $\left(\mathrm{Y}_{\mathrm{i}, \mathrm{t},-1}-\mathrm{Y}_{\mathrm{ij}, \mathrm{t}-2}\right)$ obtains the incorrect sign. Finally lambda, the only significant value falls to .18 which implies a mean lag of 2.5 months. Thus, given this implausible result and the insignificance of the coefficients this complete model is rejected.

Table 10: Full Dynamic Shortages Immigrant Demand Model:

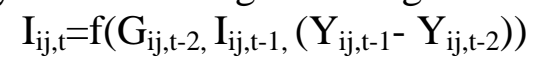

${ }^{22} \lambda /(1-\lambda)$ is the formula to calculate the mean period lag (assuming infinite number of time periods). 


\begin{tabular}{|c|c|c|c|c|c|c|}
\hline $\begin{array}{l}\text { VARIABLE } \\
\text { NAME }\end{array}$ & $\begin{array}{l}\text { ESTIMATED } \\
\text { COEFFICIENT }\end{array}$ & $\begin{array}{c}\text { STANDARD } \\
\mathrm{T} \quad \text { ERROR }\end{array}$ & T-RATIO & P-VALUE & $\begin{array}{l}\text { STANDARD. } \\
\text { COEFF. }\end{array}$ & $\begin{array}{l}\text { ELASTICITY } \\
\text { AT MEANS }\end{array}$ \\
\hline $\mathrm{I}_{\mathrm{ij}, \mathrm{t}-1}$ & 0.18708 & 0.5153E-01 & 3.63 & 0.001 & 0.1883 & 0.1842 \\
\hline$\left(Y_{i j, t-1-1}-Y_{i j, t-2}\right)$ & - 0.12776E-01 & 0.9654E-02 & -1.3222 & 0.190 & -0.0507 & -0.0016 \\
\hline $\mathrm{G}_{\mathrm{ij}, \mathrm{t}-2}$ & .002002 & .002001 & .98 & 0.362 & 0.0301 & 0.0298 \\
\hline CONSTANT & 0925.1 & .009542 & 8.0 & 0.676 & 0.000 & 0.5717 \\
\hline
\end{tabular}

$\mathrm{N}=80 \quad \mathrm{R}^{2}=.66$

Table 11: Cinquante-Cinquante Immigrant Demand Model:

$$
\mathrm{I}_{\mathrm{ij}, \mathrm{t}}=\lambda^{\mathrm{k}}\left(\mathrm{I}_{\mathrm{ij}, \mathrm{t}-1,)}\right)
$$

$\begin{array}{cllrccl}\begin{array}{c}\text { VARIABLE } \\ \text { NAME }\end{array} & \begin{array}{c}\text { ESTIMATED } \\ \text { COEFFICIENT }\end{array} & \begin{array}{c}\text { STANDARD } \\ \text { ERROR }\end{array} & \text { T-RATIO } & \begin{array}{c}\text { PARTIAL } \\ \text { P-VALUE }\end{array} & \begin{array}{c}\text { STANDARD. } \\ \text { COEFF. }\end{array} & \begin{array}{l}\text { ELASTICITY } \\ \text { AT MEANS }\end{array} \\ \mathrm{I}_{\text {ij,t-1 }}^{\mathrm{E}_{\mathrm{i}}} & 0.36649 & 0.1763 & 2.079 & 0.042 & 0.252 & 0.1796 \\ \text { CONSTANT } & 0.16278 \mathrm{E}+06 & 0.1818 \mathrm{E}+05 & 8.956 & 0.000 & 0.746 & 0.0000\end{array}$

$\mathrm{N}=80 \quad \mathrm{R}^{2}=.16$

One major policy statement of the 1990's asserted that total immigration flows were to be a multiple of the past yearly intake of economic immigrants $\left(\mathrm{I}^{\mathrm{E}} \mathrm{ij,t-1}\right)$. Table 11 reports a simple test of this proposition which a strong positive relationship between past economic immigrant inflows and contemporary immigration levels. The system moreover was stable since $\lambda^{\mathrm{k}}$ was less than unity (.36) with a mean lag of less than a year (i.e. 6 months). This latter point indicates that policy makers were keenly aware of the need to match economic immigrants to the total flow admitted six months later.

In sum, these various tests of my model indicate that for these select occupations past immigration levels and changes in occupational wage rates condition immigrant admissions over the $1980-2001$ period. $^{23}$

\section{Section IV: Brain Circulation}

I noted earlier that historically Canada was viewed as a staging ground for emigration as some Canadian immigrants left Canada to return home or move on to a third country, This movement was generally seen as a loss to Canada since it was argued that Canadian émigrés were often positively selected (DeVoretz and Laryea, 1998).

A more neutral term, "Brain Circulation", has become the favored term of the $21^{\text {st }}$ century when discussing the return migration of erstwhile highly skilled Canadian immigrants. Changing mobility conditions across a variety of sending and receiving countries in the mid-1990s led to a new and more general variant of the historical brain drain-gain issue, namely the phenomenon of 'brain circulation'. The literature defines 'brain circulation' as a series of sequential movements by highly skilled workers across three or more states (DeVoretz \& Ma, 2002). These states include the sending region, the

\footnotetext{
${ }^{23}$ Table A-4 reports the results for the complete model for the 1976-1984 which supports the existence of a 'tap on-tap off' manpower policy circa 1976-1984.
} 
initial receiving region (e.g. Canada) and the rest of world. Moreover, the movement may not be temporary. Rather substantial periods of residence may occur so that the immigrant may acquire citizenship and human capital in the receiving country before moving again (DeVoretz \& Zhang, 2004).

What new forces emerged in the 1990s to reconfigure the erstwhile bilateral brain drain into a multilateral brain circulation phenomenon? First, a robust economy in North America with an expanding IT sector fuelled the demand for highly skilled immigrants. This alone would have however simply led to a bilateral movement of skilled workers or a typical 'brain drain' in the absence of new institutional and legal frameworks. The first major institutional change was the proliferation of dual citizenship policies which allowed some highly skilled immigrants to move continuously between their erstwhile home country and the receiving country (DeVoretz and Pivnenko, 2006). In addition, the second citizenship often conferred even more extensive mobility rights. For example, naturalized Canadian citizens could now enter the United States under a NAFTA or TN visa created especially for trade related migration. In addition, to the traditional mode of permanent movement culminating in citizenship, temporary visas became more plentiful, especially the H1-B in the United States which accelerated the movement of highly skilled immigrants especially from India and China. These temporary visa holders were then often able to adjust to a permanent status in the United States or move on to the rest of the world.

Another major force emerged in the early 1990s to accelerate 'brain circulation' as China (PRC) relaxed its exit requirements to allow highly skilled Chinese to leave for educational purposes, with the expectation that at least one-third would return to China. Moreover, constraints in the Chinese educational system, including higher fees and increased competition for admission to the best schools, encouraged Chinese student immigration to North America and Australia. These students often converted their temporary student visas to a more permanent status especially in Australia which facilitated this conversion process. For its part, India instituted partial dual citizenship to Indian foreign citizens and this facilitated Indian 'brain circulation'.

In addition, the rise in foreign direct investment to the immigrant's home country financed by immigrant remittances often required the periodic presence of these immigrant investors, giving rise to transnational households. Thus, with one spouse investing and working in the sending country and one spouse in Canada, the periodic return of the erstwhile Canadian immigrant to Canada was assured and this movement back assured continuous 'brain circulation'.

Figure 2

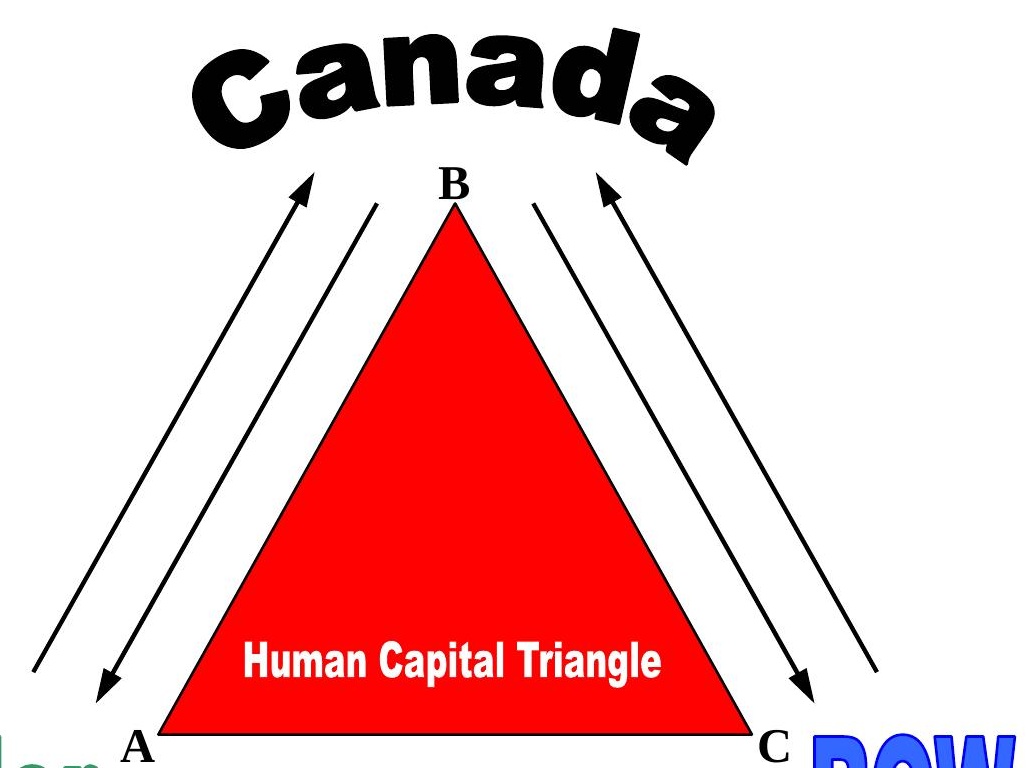


In sum, both these changing supply and demand conditions altered the bi-lateral brain drain into a triangular movement as depicted in figure 2 which has now been termed 'brain circulation'. This concept of 'brain circulation' is general enough to permit the simple unilateral brain drain (A to B) or transnational movement (A to B to A), as well as true brain circulation with movement from A to B to C.

\section{Motivations to engage in "Brain Circulation"}

In the conventional brain drain literature, bilateral movements of the highly skilled were argued to result from a series of push and pull forces in the origin and destination countries. The neo-classical view that higher expected wages in the destination country constituted the main motivation to move was replaced in the 'brain circulation' literature by an explanation which appealed to forces inherent in the more modern theory of households. This literature owing to Stark and Lucas (1988) suggested in the 1980s that households in poor countries used migration as one of many strategies to survive in an uncertain environment. Hence, households invested in the individuals' education and financed their departure for further schooling and employment under the implicit private contract that the individuals would remit monies so that poor households could survive. Thus, this modern home economics literature did not view highly skilled migration as a simple result of exogenous push and/or pull forces, but as part of households' general investment strategy.

Given the above argument, then skilled immigration will increase when the return from the joint household investment in a family member's education and immigration rises. For example, if immigrant remittances suddenly become more productive in the immigrant sending country due to exchange rate stability or low transaction costs, more immigration will be financed by the immigrant sending country households. ${ }^{24}$ In addition, if family reunification is made easier in Canada then, as a consequence 'brain circulation' will decrease since the imperative for return migration will decease. On the other hand, if the costs of return migration are reduced via mutually respected dual citizenship policies between the sending and receiving countries, the nature of highly skilled migration will change from a permanent move to a rotating strategy more consistent with the concept of brain circulation.

In addition, a distinction must be made between general motivations to move and the choice to move to a particular country. Immigrant selection criteria and economic and social conditions affect the immigrants' choice of location once the decision to move has been made. If we divide immigrant-receiving regions into destinations providing

${ }^{24}$ See DeVoretz and Vadean (2005) 
subsidized general and specific human capital versus those that offer no subsidized human capital, then immigrants will self select into either country based on their taste for risk. It has been noted that the acquisition of human capital in the destination region affects the move-stay choice of the skilled immigrants. For example, Canada provides subsidized human capital (language, job skills, and certification) to risk adverse immigrant arrivals who are attracted to a more equalitarian but lower income economy. However, whether these skilled immigrants enhanced with subsidized human capital remain in Canada depends on citizenship policies which influence downstream immigration to a third country. ${ }^{25}$

“Brain Circulation' also appears due to a series of cross country competing immigration policy initiatives. In a modern context this means that, even if the rate of return for the skilled immigrants' human capital is lower in Canada, but the queuing time is certain and shorter for a move to Canada, the immigrant may choose Canada over the United States, at least in the short run. Thus, immigration motivation is now defined by more than the simple push-pull thesis between the sending and receiving countries. This motivation is now part of a complex strategy. In other words, highly skilled immigrants maximize their net income gain by moving in a sequential pattern; first to an entrepot country, Canada, which supplies subsidized human capital, and then consider returning home or moving on to the rest of the world once they became naturalized Canadians.

In the context of brain circulation the role of push and pull forces become blurred. Many traditional pull forces, such as access to subsidized education and the prospect of Canadian citizenship with a passport, initially attract immigrants, but, once acquired, act as a push force to send immigrants home or on to a third country. Thus, discrete push and pull distinctions are no longer relevant; rather, it is the highly skilled immigrants' desire to maximize the rate of return on the acquired human capital that motivates them to stay in Canada (pull) or move on (push).

\section{North American Evidence of "Brain Circulation"}

We now turn to some evidence in the North American context to highlight Canada's historical experience with 'brain exchange” We will conclude with more recent evidence on the alleged Chinese triangular move to shed light on a particularly important example of "brain circulation" for Canada. As already noted DeVoretz and Laryea (1998) argue, Canada has traditionally received offshore immigrants to replace earlier Canadian-born emigrants to the United States. In other words, Canada was compensated for the loss of domestically trained emigrants to the United States by importing skilled immigrants from the rest of the world (see table 1). In the 1990s there was considerable debate about the existence of a Canadian "brain drain” to the United States. However, the loss of Canadian-born skilled immigrants appeared to be more than offset by the importation of skilled labour from the rest of the world. Nonetheless, there were important exceptions to this observation that can be

\footnotetext{
${ }^{25}$ See DeVoretz and Pivnenko (2006)
} 
revealed by devising a two-part analytical framework of managed and market-driven labour markets. ${ }^{26}$

In the managed labour markets there was a Canadian 'brain drain' that went largely uncompensated by world imports. In the market-driven labour market foreign inflows of skilled immigrants to Canada have more than compensated for the skilled outflows, except managers, to the United States. The imbalance in these two labour markets, a positive net inflow in the market-driven sector and the deficit in the managed labour market led observers to conclude that Canada did not suffer from a brain drain. However, this conclusion may be premature. A careful evaluation of the credentials of the presumed highly skilled immigrants to Canada in either the market-driven or public sectors indicated that immigrant credentials often did not match the Canada-trained leavers ( DeVoretz and Iturralde, 2000). Hence, in reality there was a substantial pre2001 brain drain in the public sector and for managers that was not revealed by simple aggregate number counting.

What push and pull forces led to this 'brain circulation' to the United States in the 1990s, and are these forces still active in 2005? First, immigration policy between the United States and Canada changed with the advent of the TN-1 visa under the NAFTA accord. Canadian skilled emigration to the United States had been in a period of quiescence in the 1980s partly due to the inability of Canadians to enter the United States with a permanent visa; this changed with the TN-1 visa. Secondly a stagnant Canadian public sector pushed medical professionals to leave Canada to seek employment in the United States. Finally, higher post-tax income in the United States encouraged Canadian managers and professionals to leave in the late 1990's.

The collapse of the knowledge sector in North America and the post-911 security climate has substantially reduced any brain circulation from Canada to the United States by erstwhile Canadian immigrants. Also, the use of TN visas has been restricted to a subset of Canadian-born citizens since some naturalized Canadians now face complicated visa requirements. ${ }^{27}$ More importantly, the major pull forces in the United States have disappeared, and there is now evidence of reverse flows as foreign graduate students choose Canada over the United States given the new visa requirements (DeVoretz, 2006).

In the future Canada will continue to send highly skilled Canadians to the United States, including naturalized Canadian citizens. However, the historic predominance of pull factors indicates that economic and political conditions in the United States will largely determine this flow in the market-driven labour sector.

\section{Evidence of Chinese "Brain Circulation"}

New research presents evidence on the emergence of a Chinese Canada-Hong-Kong "brain circulation". Two studies conducted by this author, one quantitative and the other

\footnotetext{
${ }^{26}$ Examples of Canadian managed labour markets are nurses, physicians, teachers, and other public sector employees whose employment depends on public sector decisions. The Canadian market driven labour market would be all other professions.

${ }^{27}$ For example, Canadian citizens born in Iran, Pakistan and other Middle Eastern countries cannot simply use a TN visa for entry into the United States.
} 
interview based provide a host of information on both the size and the selectivity of this $21^{\text {st }}$ century example of 'brain circulation”. ${ }^{28}$

Table 12 which is drawn from Hong Kong and Canada Census data depicts the differential human capital, employment and earnings characteristics between Chinese immigrant stayers and movers. ${ }^{29}$ The returning Chinese Canadians resident in HongKong are much younger (62\% under age 39 ), more educated ( $50.5 \%$ with a University education) and earned 2.2 times more mean monthly wages than their Hong-Kong born reference group. However, the Chinese immigrant staying population in Canada has an occupational distribution more heavily concentrated in the lower professional ranks and managers categories.

Thus, by 2001 the Canadian return migration process to Hong Kong was highly selective with the youngest (except children) and most educated Chinese emigrating from Canada leaving a less educated and less productive staying segment in Canada.

Table 12. Characteristics of Hong Kong-Born Returnees and Stayers in Canada: Circa 2001

\begin{tabular}{|c|c|c|c|c|c|c|c|}
\hline \multirow[b]{3}{*}{ Total } & \multicolumn{4}{|c|}{ Returnees To Hong Kong from } & \multicolumn{3}{|c|}{$\begin{array}{c}\text { Hong-Kong } \\
\text { Born Stayers in } \\
\text { Canada* }\end{array}$} \\
\hline & \multicolumn{2}{|c|}{ All } & \multirow{2}{*}{$\begin{array}{r}\text { Canada } \\
33676 \\
(39.3 \%)\end{array}$} & \multirow{2}{*}{$\begin{array}{r}\text { USA } \\
17778 \\
(20.7 \%)\end{array}$} & \multirow{2}{*}{$\begin{array}{r}\text { Others } \\
34339 \\
(40.0 \%)\end{array}$} & \multirow[b]{2}{*}{6955} & \multirow[b]{2}{*}{100.0} \\
\hline & 85793 & $100.0 \%$ & & & & & \\
\hline \multicolumn{8}{|l|}{ Age: } \\
\hline $0-19$ & 8236 & 9.6 & 9.4 & 4.4 & 11.1 & 1506 & 21.7 \\
\hline $20-29$ & 32430 & 37.8 & 37.5 & 39.4 & 37.6 & 1272 & 18.3 \\
\hline $30-39$ & 19990 & 23.3 & 21.5 & 26.1 & 23.8 & 1745 & 25.1 \\
\hline $40-49$ & 12354 & 14.4 & 14.9 & 14.4 & 14.1 & 1630 & 23.4 \\
\hline $50-59$ & 6263 & 7.3 & 8.5 & 8 & 6.3 & 413 & 5.9 \\
\hline 60 & 6434 & 7.5 & 8.1 & 7.7 & 7.1 & 389 & 5.6 \\
\hline \multicolumn{8}{|l|}{ Sex: } \\
\hline Female & 42811 & 49.9 & 53 & 48 & 49 & 3519 & 50.6 \\
\hline Male & 42982 & 50.1 & 47 & 52 & 51 & 3436 & 49.4 \\
\hline \multicolumn{8}{|c|}{ Relation to Head of Household: } \\
\hline Head & 29170 & 34.0 & 33.5 & 35.9 & 33.9 & 1966 & 28.3 \\
\hline Spouse & 14756 & 17.2 & 18.2 & 18.0 & 16.3 & 1634 & 23.5 \\
\hline Children & 32430 & 37.8 & 38.2 & 37.1 & 37.7 & 2741 & 39.4 \\
\hline Maid & 86 & 0.1 & 0.0 & 0.0 & 0.1 & $\mathrm{n} / \mathrm{a}$ & $\mathbf{n} / \mathbf{a}$ \\
\hline Others & 9351 & 10.9 & 10.1 & 9.1 & 12.0 & 614 & 8.8 \\
\hline \multicolumn{8}{|l|}{ Education: } \\
\hline Primary School or less & 9180 & 10.7 & 9.2 & 6.4 & 13.1 & 392 & 6.4 \\
\hline $\begin{array}{l}\text { Secondary School \& } \\
\text { Diploma }\end{array}$ & 31314 & 36.5 & 40.3 & 23.6 & 37.5 & 4201 & 68.2 \\
\hline Local Uni. Degree & 12612 & 14.7 & 15.3 & 15.8 & 13.9 & 1571 & 25.5 \\
\hline
\end{tabular}

${ }^{28}$ See DeVoretz, D. and K. Zhang,(2004) for details of the quantitative study.

${ }^{29}$ The stayers are defined as Hong-Kong-born immigrants with permanent residence status in Canada circa 2001. Hong-Kong returnees from Canada are defined as Hong-Kong residents circa 2001who had lived in Canada in the previous five year period. 


\begin{tabular}{|c|c|c|c|c|c|c|c|}
\hline Overseas Degree & 32687 & 38.1 & 35.2 & 54.2 & 35.5 & & \\
\hline \multicolumn{8}{|l|}{ Occupation: } \\
\hline Low Skill & 13509 & 26.7 & 25.8 & 16.9 & 30.2 & 1068 & 27.7 \\
\hline Assistant Professional & 15584 & 30.8 & 33.7 & 29.8 & 29.2 & 951 & 24.7 \\
\hline Professional & 10726 & 21.2 & 16.9 & 28.4 & 21.9 & 1038 & 26.9 \\
\hline Managerial & 10777 & 21.3 & 23.6 & 25.0 & 18.7 & 796 & 20.7 \\
\hline Total & 50596 & 100 & 100 & 100 & 100 & 3853 & 100.0 \\
\hline \multicolumn{8}{|l|}{ Earnings: } \\
\hline $1-5,999$ & 2682 & 5.3 & 5.1 & 4.4 & 5.6 & 2382 & 45.7 \\
\hline $6,000-9,999$ & 5970 & 11.8 & 10.0 & 8.3 & 14.1 & 739 & 14.2 \\
\hline $10,000-14,999$ & 12345 & 24.4 & 26.7 & 17.6 & 24.7 & 753 & 14.5 \\
\hline $15,000-19,999$ & 7994 & 15.8 & 17.0 & 17.6 & 14.7 & 552 & 10.6 \\
\hline $20,000-29,999$ & 8348 & 16.5 & 18.3 & 17.5 & 14.8 & 525 & 10.1 \\
\hline$>=30,000$ & 13256 & 26.2 & 22.8 & 34.6 & 26.0 & 256 & 4.9 \\
\hline Total & 50596 & 100.0 & 100.0 & 100.0 & 100.0 & 5207 & 100.0 \\
\hline Median (HK Dollar/month) & & 16520.38 & 16500.00 & 20000.00 & 15500.00 & & 7091.03 \\
\hline Mean (HK Dollar/month) & & 25543.01 & 23314.00 & 33682.00 & 24657.00 & & 10234.78 \\
\hline Gini Coefficient** & & .11. & .13 & .55 & .15 & & .34 \\
\hline
\end{tabular}

There is one further important conclusion to be drawn from an analysis of table 12. As noted, this return movement is welfare-improving for the migrants (higher wages) in the triangle and possibly taxpayers in Hong Kong, but not the Canadian taxpayers. Elsewhere it has been estimated by DeVoretz and Itturalde (2000) that each Canadian post-secondary student who leaves Canada takes approximately \$230,000 (Cdn) in taxpayer subsidy with him/her. Thus, combining the number of returnees reported in table 12 who acquired a post-secondary education overseas $(11,786)$ with this Canadian taxpayer subsidy yields a $\$ 2.7$ billion (Canadian) drain from Canada to Hong Kong.

One fundamental question remains. What were the reasons for this selective movement? Unfortunately census data can not reveal the motivations to return to Hong Kong and I thus conducted extensive surveys of both the Chinese stayer population in Vancouver and the mover population in Hong-Kong. ${ }^{30}$ The stayer survey asked over 900 respondents the cultural, linguistic, social and political forces which determined their degree of integration in the Canadian society and economy and their prospects of moving to Hong Kong.

Figure 3 places the Vancouver's Chinese immigrant stayers in the Vancouver economic context. The stayer reported wage earnings for Chinese immigrants after age 30, are well below the wage earnings reported for Canadians in Vancouver. These poor economic prospects, especially for Hong-Kong immigrants, should motivate their return given that their income level prospects are twice as high in Hong-Kong as in Canada (see table 12).

\footnotetext{
${ }^{30}$ The interested reader may see the surveys at http://riim.metropolis.net/research-policy/Survey/first.htm
} 
Figure 3: Mean annual wage-age earnings profiles for all occupations: Vancouver immigrants from PRC and Hong-

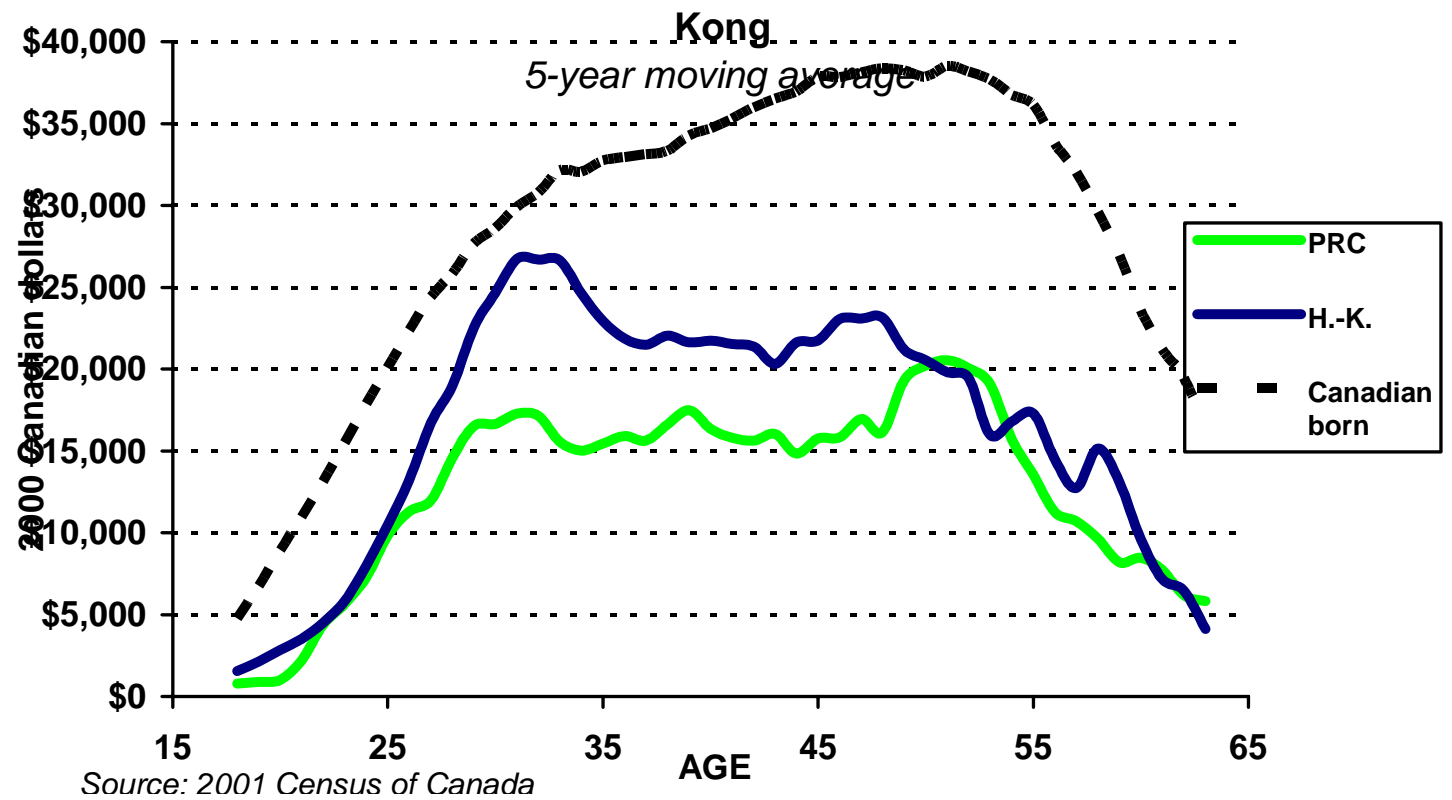

Given this weak economic performance our survey probed Chinese immigrants to explain the forces behind this poor economic performance and comment on their prospects of remaining in Canada. When asked in the survey what they felt were the barriers to employment the majority (65\%) of the Chinese respondents, regardless of skill level, attributed their labour market problems to either a lack of credential recognition, language barriers or both. In terms of meeting their social and economic aspirations after three or more years in Canada only $25 \%$ of the Chinese respondents remaining in Canada had met any of their goals and 50\% said that they never would meet these goals. When asked what social group had helped them most to integrate into society they rated family and friends first, social organizations second and government last. In terms of their future aspirations over 60 per cent planned to stay in Canada while 40 per cent were either uncertain or planned to leave once they acquired citizenship. Finally, an analysis of the motivations to stay under these dire circumstances revealed that most felt conditions would not improve for themselves but they almost universally felt (90\%) that conditions for their children would improve in Canada and they would remain in Canada for that reason.

In sum, these 945 Chinese immigrants face a variety of employment barriers, but only $40 \%$ stated that they would leave after obtaining Canadian citizenship.

\section{Implications of Return or Onward Migration}

Under the old regime of permanent settlement and limited circulation, Canada's investment in immigration integration yielded social and economic rewards from the presence of immigrants which aided Canada's development and treasury. This may no longer be the case, as Canada must now share the benefits of immigrant relocation and 
increased education with the rest of the world. ${ }^{31}$ Given the size of immigrant remittances and return migration it is now possible to argue that both the immigrant sending and receiving countries share in the immigrant's prosperity. ${ }^{32}$

This census based evidence on the economic activity of Canadian citizens who have returned to Hong-Kong documents their strong economic performance relative to the Chinese immigrants who remained in Canada. Thus, in this case, self-selection in return or onward migration is evident: the best move and the weakest remain in Canada. On balance it appears in this limited case that Canada is losing the most productive highly skilled Chinese who were trained in Canada and are now Canadian citizens residing in Hong Kong. In addition, a large financial liability may await Canadian taxpayers if these Chinese émigrés return in old age.

\section{$\underline{\text { Section V : Conclusions }}$}

This essay explored the role of Canadian immigration policy in meeting Canada's historical role of aiding Canadian economic development. In the modern setting of the 1980's through the opening of the $21^{\text {st }}$ century Canadian immigration policy has been substantially revamped. First, in terms of number of immigrant arrivals or the value of their embodied capital the occupational distribution of Canadian immigrant inflows changed dramatically from the 1980's until 2001. The supply driven entry of Hong-Kong and other managers and investors was supplanted by the emergence of engineering and associated professionals after 1995. These trends were an outgrowth of two explicit immigrant demand philosophies including the cautious 'tap on-tap off' policy of the 1980's and expansionist 'cinquante-cinquante' policy of the 1990’s. In addition, Canada moved from a 'brain gain' immigrant receiving country in the 1980's to a 'brain circulation' participant in the late 1990's as some highly talented Canadian immigrants became émigrés. Finally, Canada's expansionary immigration policy of the 1990's complemented its increased globalization position of the 1990's as exports, foreign direct investment and immigration expanded.

This flexible and modern Canadian immigration policy however has not been a robust 'engine of growth' as in the past. First, many of the recruited managers of the 1980's left in the 1990's for the United States or returned to Hong Kong. Next, the heavy recruitment of engineers was less than selective as a 'credential crisis' emerged in the $21^{\text {st }}$ century along with an oversupply. Unfortunately immigration decisions are asymmetrical since you can admit permanent immigrants but can not send them home if the economic situation changes as it did after 2001. The expansionary immigration policy of the 1990's has left Canada with a legacy of highly trained immigrants whose credentials are either not recognized or do not match Canadian standards. Thus, unlike the past these new Canadians do not experience earnings assimilation and this lowers Canada's per capita income.

\footnotetext{
${ }^{31}$ Remittances in particular have substantially grown in the last decade and they now surpass foreign aid as a source of development funds for many countries ( Straubhaar and Vadean, 2005).

${ }^{32}$ See DeVoretz and Vadean (2005) for estimates of Canadian immigrant remittances.
} 
What future policy directions are available to make immigration a handmaiden of growth? In the short run Canada can revamp its immigration policy to more closely align itself with Australia's policy by recruiting Canada's highly skilled immigrants from its foreign student population. Recent policy initiatives (May, 2005) indicate that Canada may be partially moving in this direction as it grants more generous work permits to foreign student graduates. ${ }^{33}$ This recruitment of foreign students would alleviate the credential recognition problem and minimize the reported linguistic and cultural impediments that current overseas recruited immigrants face (DeVoretz, 2005) If Canada does not become more competitive in the immigrant recruitment process it faces long run challenges. Canada can only hope that second generation immigrants produce the results that it expected from first generation immigrants. As Canada waits this long-run positive outcome, selective out migration of productive first generation immigrants will occur further undermining immigration as a handmaiden of economic growth.

\footnotetext{
${ }^{33}$ Foreign students circa 2005 can be granted two year work permits if they find a job outside of Vancouver, Toronto or Montreal. During this two year period they can apply for permanent immigration status and earn the all important Canadian job experience to hasten economic assimilation.
} 


\section{References}

Akbari, S. A. and D. J. DeVoretz (1988). The substitutability of foreign-born labor in Canadian production circa 1980. Ottawa: Canada Employment and Immigration.

Arrow K. and W. Capron (1959). Dynamic shortages and price rises: Scientist case. Quarterly Journal of Economics, May.

Bruder, J. (200) “ Are Trade and Migration Substitutes or Complements? -The Case of Germany, 1970-1998. IZA Working Paper.

Canada. Annual Salaries of Hospital Nursing Personnel. Ottawa: Statistics Canada, various issues.

Canada. Degrees, Diplomas, Certificates Awarded by Degree Granting Institutions. Ottawa: Statistics Canada, various issues.

Canada. Degrees, Diplomas, Certificates Awarded by Universities. Ottawa: Statistics Canada, various issues.

Canada. Education in Canada. Ottawa: Statistics Canada, various issues.

Canada. Immigration Statistics. Ottawa : Department of Employment and Immigration, various issues.

Canada. Salaries and Qualifications of Teachers in Elementary and Secondary Schools. Ottawa: Statistics Canada, various issues.

Canada (1976). The Immigration Bill. Ottawa: Department of Manpower and Immigration.

Coulson, R. and D. J. DeVoretz (1989). Human capital content of Canadian immigration: 1966-1987. Paper presented at the $16^{\text {th }}$ Conference on the Use of Quantitative Methods in Canadian Economic History, Toronto.

D. DeVoretz, (2000) “An Analysis of Turn-of-the-Century Canadian Immigration: 18911914.” RIIM Working Paper \#00-21, Simon Fraser University.

DeVoretz, D. J. (2003) “Asian Skilled Immigration Flows to Canada in the early $21^{\text {st }}$ Century: A Supply-side Analysis”. In Y.P. Woo (ed.), Canada’s Foreign Policy Dialogue and Canada-Asia Relations. Vancouver: Asia Pacific Foundation of Canada. 2003.

DeVoretz, D. (2005) “ Brief to the House of Commons Standing Committee on Citizenship and Immigration, RIIM Commentary Series 05-01E. 
DeVoretz, D. (2006a) "Immigration Policy: Methods of Economic Assessment" International Migration Review, Summer 2006, Vol. 40, No. 2.

DeVoretz, D. (2006b) “The Education, Immigration and Emigration of Canada’s Highly Skilled Workers in the $21^{\text {st }}$ Century, Forthcoming Sloan Foundation.

DeVoretz, D. J. and D. Maki (1983). The Immigration of Third World Professionals to Canada: 1968-1973. World Development, 11 (1): 55-64.

DeVoretz, D. J., and C. Itturalde. 2000. Probability of Staying in Canada. RIIM Working Paper 00-06.

DeVoretz, D. and S. Laryea, (1998) “Migration and the Labour market: Sectoral and Regional effects in Canada.” In Migration, Free Trade and Regional Integration in North America, OECD Proceedings, 30: 135-153.

DeVoretz, D. and J. Ma, (2002) “Triangular Human Capital Flows between Sending, Entrepot and the Rest of the World's Regions”, Canadian Population Studies, 29(1):5369.

DeVoretz, D. and D. Coulombe, (2005) Labour Market Mobility between Canada and the United States: Quo vadis? In T. Lemieux and R. Harris (eds.), Social and Labour Market Aspects of North American Linkages. Calgary: University of Calgary Press.

DeVoretz, D. and K. Zhang,(2004) Citizenship, Passports and the Brain Exchange Triangle. Journal of Comparative Policy Analysis, 6(2): 199-212.

DeVoretz, D. and S. Pivnenko (2004) “The Economic Experiences of Refugees in Canada.” In P. Waxman and V. Colic-Peisker (eds.), Homeland Wanted:

Interdisciplinary Perspective on Refugee Settlement in the West, Ch. 1. New York: Nova Science Publishers.

DeVoretz, D. and F. Vadean (2005) A Model of Foreign-born Transfers: Evidence from Canadian Micro data RIIM Working Paper \#05-17.

DeVoretz, D. and S. Pivnenko, (2006) “The Economics of Canadian Citizenship” Journal of Immigration and Integration

Gera, S., S. Laryea and T. Songsakul (2004) "International Mobility of Skilled Labour: Analytical and Empirical Issues, and Research Priorities” HRDC-IC-SSHRC Skills Research Initiative Working Paper 2004 D-01.

Globerman, S. (1995) “Immigration and Trade“ in D. DeVoretz (ed.) Diminishing Returns: The Economics of Canadian Immigration (Toronto: C. D. Howe). 
(1999) “Trade Liberalization and the Migration of Skilled Workers”, in

Perspectives on North American Free Trade, Industry Canada, Paper number 3.

Green, A. and D. Green, (1996) “The Economic Goals of Canada’s Immigration Policy:

Past and Present“ RIIM Working Paper, 1996-04.

Markusen, James R. (1983), “Factor Movement and Commodity Trade as Complements”, Journal of International Economics, Vol. 14, pp. 341-356.

Mosk, C. (2005) Trade and Migration in the Modern World (New York: Routledge).

Mundell, Robert A. (1957): "International Trade and Factor Mobility,” American Economic Review, 47, pp. 321-35.

Pomfret, R. (1993) The Economic Development of Canada, (Scarborough; Nelson, Canada)

Reitz, J.G. (2005). Tapping Immigrants' Skills: New Directions for Canadian Immigration Policy in the Knowledge Economy. IRPP Choices, 11(1): 2-15.

Shi, Y. (2004) “The Impact of Canada’s New Immigration Act on Chinese Independent Immigrants. “, Canadian Journal of Urban Research, 13(1):140-54.

Stark, O., and R. Lucas, (1988), “Migration, Remittance and the Family”, Economic Development and Cultural Change, Vol. 31, pp: 191-196.

Williamson, J.G., W. Collins and K. O’Rourke (1999) “Were Trade and Factor Mobility Substitutes in History?" in R. Faini, J. DeMelo and K. Zimmermann (eds.), Migration: The Controversies and the Evidence (Cambridge:Cambridge University Press, 1999).

Straubhaar, T. and F. Vadean (2005) "International Migrant Remittances and their Role in Development”, OECD.

Worswick, C. (2004). Immigrants' Declining Earnings: Reasons and Remedies. Toronto: C. D. Howe Institute Backgrounder series, No. 81.

United States Immigration and Naturalization Services. Annual Report. Washington, DC: Department of Justice, various years.

Zhao, John, Doug Drew and T. Scott Murray (2000) "Brain Drain and Brain Gain: The Migration of Knowledge Workers from and to Canada “ Education Quarterly Review, Vol. 6 (3) pp.8-35. 


\section{APPENDIX A}

\section{Table A-1. Variable définitions}

(1)

Variables

1. Immigrants

Earnings

(a) Teachers

(b) Professors

(c) Physicians

(d) Nurses
(2)

Operational definitions
(3)

Sources
Teachers, professors, physicians and nurses entering Canada during 1975-86 under immigrant visas from 16 countries.

Median real annual salaries for all public secondary and elementary school teachers.

Median real salaries of full-time university teachers.

Net annual real earnings of self-employed physicians and surgeons.

Mean real salaries of graduate nurses employed in Canada.
Canada, Salaries and Qualificationsf

Teachers in Public Elementary and Secondary Schools (various issues).

Canada, Education in Canada (Various issues).

Canada (various issues).

Canada (various issues).

3. Lagged Canadian graduates

(a) Teachers

(b) Professors

(c) Physicians

(d) Nurses
Bachelor and Master of Education degrees granted in Canadian universities and colleges. All earned doctorates granted in all fields in Canada.

MD and Master of Medicine degrees granted in Canadian universities and colleges.

Bachelor of Nursing degrees granted in Canadian universities and colleges.

4. Immigration to United States
Immigration levels to the United States in each occupational category: professional, technical and managerial.
For all categories used: Canada, Degrees, Diplomas, Certificates Awarded by Degree Granting Institutions (various issues).

US INS (various years). 
Table A-2 . Trends in Canadian Immigration 1980-2001 (absolute numbers in 000s)

\begin{tabular}{crrr}
\hline & & \multicolumn{2}{c}{ Immigrants } \\
& & \multicolumn{2}{c}{ Professionals* } \\
\cline { 3 - 4 } Year & $\begin{array}{c}\text { Total } \\
\text { Immigration }\end{array}$ & $\begin{array}{c}\text { Total } \\
\text { Try }\end{array}$ & $\begin{array}{c}\text { as } \% \text { of } \\
\text { All }\end{array}$ \\
\hline 1980 & 142,856 & 11,067 & $7.75 \%$ \\
1981 & 128,311 & 13,369 & $10.42 \%$ \\
1982 & 120,616 & 14,404 & $11.94 \%$ \\
1983 & 88,617 & 7,766 & $8.76 \%$ \\
1984 & 87,236 & 6,560 & $7.52 \%$ \\
1985 & 82,822 & 6,643 & $8.02 \%$ \\
1986 & 97,509 & 8,245 & $8.46 \%$ \\
1987 & 149,515 & 15,290 & $10.23 \%$ \\
1988 & 158,499 & 16,503 & $10.41 \%$ \\
1989 & 188,148 & 18,154 & $9.65 \%$ \\
1990 & 213,009 & 19,517 & $9.16 \%$ \\
1991 & 229,693 & 16,870 & $7.34 \%$ \\
1992 & 250,550 & 15,868 & $6.33 \%$ \\
1993 & 252,194 & 18,836 & $7.47 \%$ \\
1994 & 220,500 & 20,945 & $9.50 \%$ \\
1995 & 209,726 & 24,646 & $11.75 \%$ \\
1996 & 222,728 & 31,099 & $13.96 \%$ \\
1997 & 208,582 & 33,507 & $16.06 \%$ \\
1998 & 163,446 & 27,770 & $16.99 \%$ \\
1999 & 183,308 & 34,870 & $19.02 \%$ \\
2000 & 222,352 & 45,282 & $20.37 \%$ \\
2001 & 246,892 & 50,206 & $20.34 \%$ \\
*All managerial and professional occupations & & & \\
Source: LIDS & & &
\end{tabular}


Table A-3 Real annual wage earnings of immigrants by occupation, one year after arrival,

\begin{tabular}{|c|c|c|c|c|c|c|c|}
\hline Year & $\begin{array}{l}\text { Managerial and } \\
\text { Administrative }\end{array}$ & $\begin{array}{l}\text { Scientists } \\
\text { (Natural } \\
\text { and Life } \\
\text { Sciences) }\end{array}$ & $\begin{array}{l}\text { Engineers } \\
\text { and } \\
\text { Architects }\end{array}$ & $\begin{array}{l}\text { Canadian dolla } \\
\text { Nursing, } \\
\text { Therapy and } \\
\text { Related } \\
\text { Assisting } \\
\text { Occupations }\end{array}$ & $\begin{array}{l}\text { Teaching } \\
\text { Occupations }\end{array}$ & $\begin{array}{l}\text { Professional } \\
\text { Occupations } \\
\text { in Art and } \\
\text { Culture }\end{array}$ & $\begin{array}{l}\text { Professional } \\
\text { Occupations in Social } \\
\text { Science, Government } \\
\text { Services and Religion }\end{array}$ \\
\hline 1981 & $\$ 46,560$ & $\$ 38,053$ & $\$ 48,222$ & $\$ 24,248$ & $\$ 21,576$ & $\$ 19,098$ & $\$ 24,290$ \\
\hline 1982 & $\$ 44,505$ & $\$ 33,968$ & $\$ 46,890$ & $\$ 25,810$ & $\$ 24,652$ & $\$ 16,726$ & $\$ 23,906$ \\
\hline 1983 & $\$ 42,026$ & $\$ 28,279$ & $\$ 36,234$ & $\$ 24,790$ & $\$ 24,213$ & $\$ 13,991$ & $\$ 21,950$ \\
\hline 1984 & $\$ 44,214$ & $\$ 29,845$ & $\$ 29,949$ & $\$ 25,341$ & $\$ 19,441$ & $\$ 13,336$ & $\$ 20,886$ \\
\hline 1985 & $\$ 44,229$ & $\$ 29,107$ & $\$ 29,983$ & $\$ 25,321$ & $\$ 19,671$ & $\$ 13,207$ & $\$ 22,447$ \\
\hline 1986 & $\$ 45,708$ & $\$ 31,328$ & $\$ 30,155$ & $\$ 25,029$ & $\$ 19,108$ & $\$ 15,798$ & $\$ 20,548$ \\
\hline 1987 & $\$ 41,066$ & $\$ 27,779$ & $\$ 29,179$ & $\$ 25,293$ & $\$ 19,583$ & $\$ 16,704$ & $\$ 20,177$ \\
\hline 1988 & $\$ 35,022$ & $\$ 26,446$ & $\$ 30,505$ & $\$ 24,130$ & $\$ 21,070$ & $\$ 18,165$ & $\$ 22,149$ \\
\hline 1989 & $\$ 32,511$ & $\$ 24,674$ & $\$ 31,498$ & $\$ 22,510$ & $\$ 21,939$ & $\$ 17,740$ & $\$ 20,517$ \\
\hline 1990 & $\$ 30,780$ & $\$ 23,678$ & $\$ 28,345$ & $\$ 23,210$ & $\$ 22,026$ & $\$ 17,912$ & $\$ 20,851$ \\
\hline 1991 & $\$ 24,241$ & $\$ 21,372$ & $\$ 24,218$ & $\$ 20,147$ & $\$ 22,028$ & $\$ 13,699$ & $\$ 17,636$ \\
\hline 1992 & $\$ 27,368$ & $\$ 24,110$ & $\$ 23,342$ & $\$ 21,483$ & $\$ 21,259$ & $\$ 13,270$ & $\$ 20,092$ \\
\hline 1993 & $\$ 29,315$ & $\$ 26,512$ & $\$ 21,823$ & $\$ 25,879$ & $\$ 23,006$ & $\$ 13,054$ & $\$ 21,280$ \\
\hline 1994 & $\$ 28,878$ & $\$ 23,501$ & $\$ 22,107$ & $\$ 23,259$ & $\$ 19,047$ & $\$ 13,687$ & $\$ 19,214$ \\
\hline 1995 & $\$ 29,957$ & $\$ 18,810$ & $\$ 21,580$ & $\$ 22,364$ & $\$ 16,005$ & $\$ 13,406$ & $\$ 17,981$ \\
\hline 1996 & $\$ 23,400$ & $\$ 19,196$ & $\$ 21,064$ & $\$ 19,965$ & $\$ 13,706$ & $\$ 12,505$ & $\$ 16,110$ \\
\hline 1997 & $\$ 20,926$ & $\$ 17,331$ & $\$ 20,855$ & $\$ 16,629$ & $\$ 12,095$ & $\$ 12,944$ & $\$ 15,147$ \\
\hline
\end{tabular}


Table A-4. Parameter estimates for Canadian lagged endogenous immigrant demand function : 1975-86

\begin{tabular}{|c|c|c|c|c|c|}
\hline \multicolumn{6}{|c|}{ Independent Regression } \\
\hline & Variable & \multicolumn{2}{|c|}{ coefficient } & \multicolumn{2}{|l|}{$T$-value } \\
\hline \multicolumn{6}{|c|}{ Panel A : } \\
\hline \multicolumn{6}{|c|}{ Model I: Log-linear OLS* } \\
\hline \multirow{6}{*}{\multicolumn{2}{|c|}{$\begin{array}{l}Y_{j, t} \\
G_{j, t} \\
G_{j, t}, \\
{ }_{I} S_{i j,}\end{array}$}} & & -2.52 & -1.66 & \\
\hline & & & Income & 0.20 & 1.99 \\
\hline & & & Grad Lag & -0.91 & -1.91 \\
\hline & & & Grad Lag & 1.03 & 2.16 \\
\hline & & & Mig US & 0.01 & 0.23 \\
\hline & & & Mig Lag & 0.65 & 14.4 \\
\hline & S.E.E. $=0.685$ & $\mathrm{R}^{2}=0.52$ & 2 Numbe & bbservation & \\
\hline \multicolumn{6}{|c|}{ Panel B: } \\
\hline \multicolumn{6}{|c|}{ Model II: Log-linear GLS* } \\
\hline \multirow{6}{*}{\multicolumn{2}{|c|}{$\begin{array}{c}Y_{j, t-1} \\
G_{j, t-1} \\
G_{j, t-2} \\
I_{S}{ }_{i j, t-1} \\
I_{i j, t-1}\end{array}$}} & & -0.251 & -1.66 & \\
\hline & & & Income & 0.21 & 1.75 \\
\hline & & & Grad Lag & -1.11 & -2.03 \\
\hline & & & Grad Lag & 1.22 & 2.253 \\
\hline & & & Mig US & 0.01 & 0.21 \\
\hline & & & Mig Lag & 0.65 & 9.4 \\
\hline & S.E.E. $=0.666$ & $\mathrm{R}^{2}=0.53$ & 3 Numbe & bbservatiol & \\
\hline
\end{tabular}

* Source: DeVoretz and Maki (1983) 
Table A-5A. Immigration to Canada by occupation, 1980-1990

\begin{tabular}{lrrrrrrrrrrrrr} 
& 1980 & 1981 & 1982 & 1983 & 1984 & 1985 & 1986 & 1987 & 1988 & 1989 & 1990 & TOTAL \\
\cline { 2 - 8 } Managerial & 2,599 & 2,848 & 2,960 & 2,088 & 1,748 & 1,677 & 2,090 & 4,630 & 5,394 & 5,465 & 5,792 & 37,291 \\
Engineers & 1,236 & 2,133 & 2,630 & 965 & 693 & 679 & 896 & 1,647 & 1,563 & 1,895 & 2215 & 16,552 \\
Natural Scientists & 559 & 617 & 674 & 341 & 279 & 298 & 336 & 518 & 560 & 729 & 730 & 5,641 \\
University Professors & 482 & 334 & 339 & 262 & 246 & 291 & 341 & 349 & 284 & 397 & 413 & 3,738 \\
Teachers & 766 & 751 & 775 & 501 & 459 & 496 & 563 & 798 & 859 & 1,144 & 1,368 & 8,480 \\
Physician & 510 & 555 & 607 & 451 & 449 & 449 & 553 & 567 & 483 & 654 & 668 & 5,946 \\
Nurses & 660 & 983 & 1,006 & 362 & 303 & 283 & 392 & 741 & 1,045 & 1,185 & 1,277 & 8,237 \\
Medical tech. & 1,124 & 925 & 961 & 619 & 512 & 559 & 679 & 1,064 & 1,188 & 1,526 & 1,558 & 10,715 \\
Other professionals & 3,290 & 4,087 & 4,420 & 2,112 & 1,762 & 1,796 & 2,365 & 5,102 & 5,424 & 5,457 & 5,783 & 41,598 \\
\hline TOTAL & 11,226 & 13,233 & 14,372 & 7,701 & 6,451 & 6,528 & 8,215 & 15,416 & 16,800 & 18,452 & 19,804 & $\mathbf{1 3 8 , 1 9 8}$ \\
\hline
\end{tabular}

Source: Landed Immigrants Data System (LIDS), Citizenship and Immigration Canada

Table A-5B. Immigration to Canada by occupation, 1991-2001

\begin{tabular}{|c|c|c|c|c|c|c|c|c|c|c|c|c|}
\hline & 1991 & 1992 & 1993 & 1994 & 1995 & 1996 & 1997 & 1998 & 1999 & 2000 & 2001 & TOTAL \\
\hline Managerial & 3,913 & 3,650 & 3,180 & 2,486 & 1,943 & 1,948 & 1,696 & 1,329 & 1,730 & 2,508 & 3,064 & 27,447 \\
\hline Engineers & 2,095 & 2,143 & 3,535 & 4,504 & 6,012 & 8,094 & 9,574 & 8,473 & 11,505 & 15,447 & 16,874 & 88,256 \\
\hline Natural Scientists & 736 & 600 & 743 & 1,307 & 1,882 & 2,698 & 2,877 & 2,328 & 2,727 & 2,842 & 2,726 & 21,466 \\
\hline University Professors & 541 & 493 & 453 & 312 & 267 & 248 & 192 & 210 & 222 & 273 & 309 & 3,520 \\
\hline Teachers & 1,140 & 940 & 1,027 & 778 & 660 & 721 & 539 & 470 & 457 & 675 & 771 & 8,178 \\
\hline Physician & 686 & 631 & 688 & 546 & 520 & 592 & 537 & 451 & 436 & 592 & 674 & 6,353 \\
\hline Nurses & 1,165 & 1,027 & 877 & 831 & 634 & 421 & 351 & 249 & 243 & 327 & 439 & 6,564 \\
\hline Medical tech. & 1,285 & 1,048 & 1,088 & 1,001 & 1,087 & 1,235 & 1,256 & 915 & 992 & 1,299 & 1,517 & 12,723 \\
\hline Other professionals & 5,346 & 5,274 & 6,849 & 8,616 & 11,092 & 14,329 & 15,733 & 12,592 & 15,745 & 20,339 & 22,895 & 138,810 \\
\hline TOTAL & 16,907 & 15,806 & 18,440 & 20,381 & 24,097 & 30,286 & 32,755 & 27,017 & 34,057 & 44,302 & 49,269 & 313,317 \\
\hline
\end{tabular}

Source: Landed Immigrants Data System (LIDS), Citizenship and Immigration Canada 
